Key Words:

Environment

Remediation

Retention:

Permanent

\title{
Detecting and Quantifying Reductive Dechlorination During Monitored Natural Attenuation at the Savannah River CBRP Site
}

\begin{abstract}
(A Research Study of the Monitored Natural Attenuation/Enhanced Attenuation for Chlorinated Solvents Technology Alternative Project)
\end{abstract}

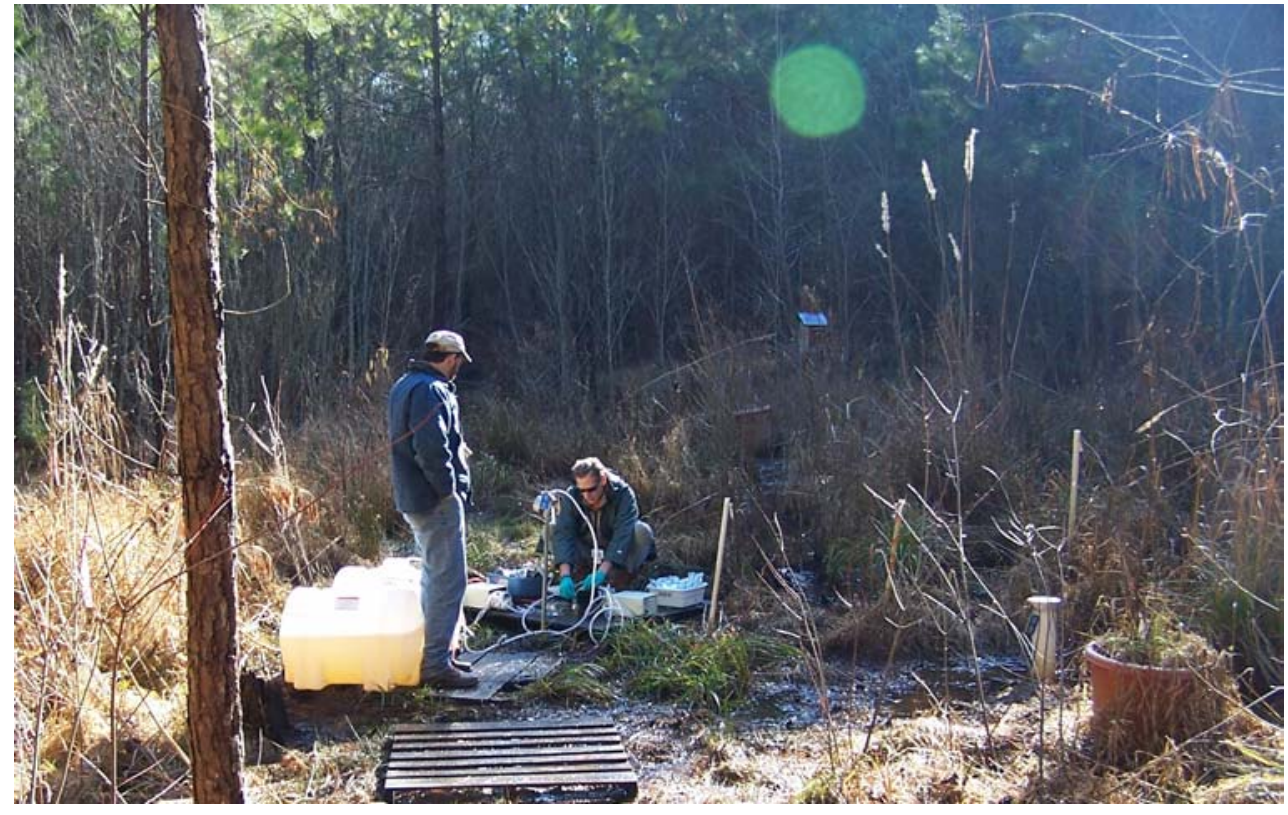

January 2, 2007

Washington Savannah River Company Savannah River Site Aiken, SC 29808 
WSRC-STI-2006-00340, Rev. 0

\section{DISCLAIMER}

Preparation of this report was coordinated by Washington Savannah River Company (WSRC) for the United States Department of Energy (US DOE) under Contract No. DE-AC09-96SR18500. Extensive effort was made by the authors to assure the accuracy of the contents and interpretation. However, the USDOE nor WSRC, nor any of their employees makes any warranty, expressed or implied, or assumes any legal liability or responsibility for accuracy, completeness, or usefulness, of any information, apparatus, or product or process disclosed herein or represents that its use will not infringe privately owned rights. Reference herein to any specific commercial product, process, or service by trade name, trademark, name, manufacturer or otherwise does not necessarily constitute or imply endorsement, recommendation, or favoring of same by Washington Savannah River Company or by the United States Government or any agency thereof. The views and opinions of the authors expressed herein do not necessarily state or reflect those of the United States Government or any agency thereof.

Printed in the United States of America

Prepared For

U.S. Department of Energy 
WSRC-STI-2006-00340, Rev. 0

Key Words:

Environment

Remediation

Retention:

Permanent

\title{
Detecting and Quantifying Reductive Dechlorination During Monitored Natural Attenuation at the Savannah River CBRP Site
}

(A Research Study of the Monitored Natural Attenuation/Enhanced Attenuation for Chlorinated Solvents Technology Alternative Project)

\author{
Contributing Researchers: \\ Jack D. Istok, Oregon State University \\ Jennifer A. Field, Oregon State University \\ Eric Raes, Engineering and Land Planning Associates \\ Margaret R. Millings, SRNL \\ Aaron D. Peacock, Microbial Insights, Inc. \\ Introduced by: \\ Karen Vangelas, SRNL \\ Brian B. Looney, SRNL
}

January 2, 2007

Washington Savannah River Company
Savannah River Site
Aiken, SC 29808
$\begin{aligned} & \text { Prepared for the U.S. Department of Energy } \\ & \text { Under Contract Number DEAC09-96- } \\ & \text { SR18500 }\end{aligned}$




\section{Executive Summary}

Various attenuation mechanisms control the destruction, stabilization, and/or removal of contaminants from contaminated subsurface systems. Measuring the rates of the controlling attenuation mechanisms is a key to employing mass balance as a means to evaluate and monitor the expansion, stability and subsequent shrinkage of a contaminant plume. A team of researchers investigated the use of push-pull tests for measuring reductive dechlorination rates in situ at sites with low chlorinated solvent concentrations ( $<1 \mathrm{ppm})$. The field research also examined the synergistic use of a suite of geochemical and microbial assays. Previous push-pull tests applied to environmental remediation objectives focused on general hydrological characterization or on designing bioremediation systems by examining the response of the subsurface to stimulation. In this research, the push-pull technique was tested to determine its "low-range" sensitivity and uncertainty. Can these tests quantify relatively low attenuation rates representative of natural attenuation? The results of this research indicate that push-pull testing will be useful for measurement of in situ reductive dechlorination rates for chlorinated solvents at "Monitored Natural Attenuation" (MNA) sites. Further, using principal component analysis and other techniques, the research confirmed the usefulness of multiple lines of evidence in site characterization and in upscaling measurements made in individual wells - especially for sites where there is a geochemical gradient or varying geochemical regimes within the contaminant plume.

\section{Introduction}

Page I-ii of I-vi

Over the past three decades, much

progress has been made in the remediation of soil and groundwater contaminated by chlorinated solvents. Yet these pervasive contaminants continue to present a significant challenge to the U.S. Department of Energy (DOE), other federal agencies, and other public and private organizations. The physical and chemical properties of chlorinated solvents make it difficult to rapidly reach the low concentrations typically set as regulatory limits. These technical challenges often result in high costs and long remediation time frames. In 2003, the DOE through the Office of Environmental Management funded a science-based technical project that uses the U.S. Environmental Protection Agency's technical protocol (EPA, 1998) and directives (EPA, 1999) on Monitored Natural Attenuation (MNA) as the foundation on which to introduce supporting concepts and new scientific developments that will support remediation of chlorinated solvents based on natural attenuation processes. This project supports the direction in which many site owners want to move to complete the remediation of their site(s), that being to complete the active treatment portion of the remedial effort and transition into MNA.

The overarching objective of the effort was to examine environmental remedies that are based on natural processes remedies such as Monitored Natural

Attenuation (MNA) or Enhanced Attenuation (EA). The research program did identify several specific opportunities for advances based on: 1) mass balance as the central framework for attenuation based remedies, 2) scientific advancements and achievements during the past ten years, 3) regulatory and policy development and real-world experience using MNA, and 4) exploration of various ideas for integrating attenuation 
remedies into a systematic set of "combined remedies" for contaminated sites. These opportunities are summarized herein and are addressed in more detail in referenced project documents and journal articles, as well as in the technical and regulatory documents being developed within the Interstate Technology and Regulatory Council.

Three topic areas were identified to facilitate development during this project. Each of these topic areas, 1) mass balance, 2) enhanced attenuation (EA), and 3) innovative characterization and monitoring, was explored in terms of policy, basic and applied research, and the results integrated into a technical approach. Each of these topics is documented in stand alone reports, WSRC-STI-2006-00082, WSRC-STI-2006-00083, and WSRC-STI-2006-00084, respectively. In brief, the mass balance efforts are examining methods and tools to allow a site to be evaluated in terms of a system where the inputs, or loading, are compared to the attenuation and destruction mechanisms and outputs from the system to assess if a plume is growing, stable or shrinking. A key in the mass balance is accounting for the key attenuation processes in the system and determining their rates. EA is an emerging concept that is recognized as a transition step between traditional treatments and MNA. EA facilitates and enables natural attenuation processes to occur in a sustainable manner to allow transition from the primary treatment to MNA. EA technologies are designed to either boost the level of the natural attenuation processes or decrease the loading of contaminants to the system for a period of time sufficient to allow the remedial goals to be met over the long-term. For characterization and monitoring, a phased approach based on documenting the site specific mass balance was developed. Tools and techniques to support the approach included direct measures of the biological processes and various tools to support cost-effective long-term monitoring of systems where the natural attenuation processes are the main treatment remedies. The effort revealed opportunities for integrating attenuation mechanisms into a systematic set of "combined remedies" for contaminated sites.

An important portion of this project was a suite of 14 research studies that supported the development of the three topic areas. A research study could support one or more of these three topic areas, with one area identified as the primary target. The following report documents the results of the evaluation of applying push-pull tests as a field method to measure in situ rates of reductive dechlorination for sites with low concentrations of chlorinated solvents $(<1 \mathrm{ppm})$ that are either being considered for or in a state of MNA. This effort was led by Aaron Peacock of Microbial Insights and Jack Istok of Oregon State. This study supports the topic area(s) of characterization and monitoring and mass balance. The research challenge was to develop and field test technologies to determine microbial processes in situ using a method that will integrate over distance and volume. The objective of this research project was to expand the role of push-pull tests in characterizing contaminated groundwater to meet the above described research challenge. Previous push-pull tests that were applied to environmental remediation objectives used geochemical measurements to estimate hydrologic properties and/or used amendment solutions during the push phase to help design bioremediation. The bioremediation design work has been for both organic contaminants such as chlorinated solvents and for metals/radionuclides, such as uranium and technetium. In the DOE MNA/EA project the researchers expanded the measured parameters to include 
WSRC-STI-2006-00340, Rev. 0

January 2, 2007

Page I-iv of I-vi

microbial assays and focused on unamended systems. The test results were evaluated for the ability to use the field data to determine natural attenuation rates within the system.

The results of the combined tests were used to assess the ongoing and potential microbial processes occurring in situ and direct field-scale correlations between microbial dynamics and degradation rates and potential.

The results of the study indicated that push-pull tests using contaminant surrogates provided information from a relatively large subsurface volume (circa 0.1 to $0.3 \mathrm{~m}^{3}$ ) under field conditions and provided sufficient sensitivity to estimate natural attenuation rates in most wells. Zero-order transformation rates of trichlorofluoroethene (a surrogate for trichloroethene) ranged from $<0.05$ to $1.00 \mathrm{nM} / \mathrm{hr}$. The data correlated with geochemical measurements and principal component analysis to provide practical and useful input to mass balance modeling efforts - two major geochemical and microbial regimes were identified. These regimes, using appropriate field-measured contaminant transformation rates for each, can be incorporated into future contaminant fate and transport models. This study demonstrated for the first time that push-pull tests with reactive tracers can be used to detect and quantify reductive dechlorination of chlorinated ethenes and ethanes under monitored natural attenuation conditions.

As the MNA/EA project's Technical Working Group (TWG) evaluated the importance of mass balance in determining if an attenuation-based remedy would be appropriate for a site, they identified the need to measure the rates of the various attenuation mechanisms. For the most part these rates are estimated based on combining various data sets. A lowcost characterization method that would result in the measure of the in situ rates of attenuation would provide valuable input data for mass balance calculations.

The TWG was supportive of this project in that it provides a method to measure in situ rates of attenuation in a cost efficient manner over a large spatial area and the results can be inputted into site groundwater fate and transport models and evaluations/projections of future conditions/sustainability. TWG members found the use of the principal components analysis an innovative approach for ordination and grouping of wells and defining zones of a plume with distinct characteristics. They also noted the researchers effectively integrated chlorinated solvent and daughter products data, geochemical data and data from the use of molecular biological tools with the push-pull test data to provide supporting evidence for their results. Because this is the first time push-pull tests were used for this application it was noted by the TWG that additional tests of this application should be conducted at other locations to validate its use. 
WSRC-STI-2006-00340, Rev. 0

January 2, 2007

Page I-v of I-vi

\section{References for Introduction}

EPA, 1998. Technical Protocol for Evaluating Natural Attenuation of Chlorinated Solvents in Groundwater, EPA/600/R-98/128. Washington DC. September 1998.

EPA, 1999. Use of Monitored Natural Attenuation at Superfund, RCRA Corrective Action and Underground Storage Tank Sites, OSWER Directive 9200.4-17P. Washington DC. April 21, 1999.

WSRC-STI-2006-00082, 2006. Mass Balance: A Key to Advancing Monitored and Enhanced Attenuation for Chlorinated Solvents. Washington Savannah River Company, Aiken, SC, 29808. June 2006. Available at www.osti.gov.

WSRC-STI-2006-00083, 2006. Enhanced Attenuation: A Reference Guide on Approaches to Increase the Natural Treatment Capacity of a System, Revision 1. Washington Savannah River Company, Aiken, SC, 29808. August 2006. Available at www.osti.gov.

WSRC-STI-2006-00084, 2006. Characterization and Monitoring of Natural Attenuation of Chlorinated Solvents in Ground Water: A Systems Approach, Revision 1. Washington Savannah River Company, Aiken, SC, 29808. August 2006. Available at www.osti.gov. 
WSRC-STI-2006-00340, Rev. 0

January 2, 2007

Page I-vi of I-vi

This page intentionally left blank. 
Final Report: Detecting and quantifying reductive dechlorination during monitored natural attenuation at the Savannah River CBRP site J.D. Istok ${ }^{1}$, J.A. Field ${ }^{2}$, E. Raes ${ }^{3}$, Margaret R. Millings ${ }^{4}$ and A.D. Peacock ${ }^{5}$

${ }^{1}$ Department of Civil Engineering Oregon State University Jack.Istok@orst.edu (541) 737-8547
${ }^{2}$ Department of Environmental and Molecular Toxicology Oregon State University Jennifer.Field@orst.edu (541) 737-2265

${ }^{3}$ Engineering and Land Planning Associates

ERaes@elp-inc.com (908) 238-0544

\title{
${ }^{4}$ Savannah River National Laboratory \\ Margaret.Millings@srnl.doe.gov \\ 803-725-6230
}

\author{
${ }^{5}$ Microbial Insights, Inc. \\ APeacock@microbe.com \\ (865) 573-8188
}




\section{ABSTRACT}

Field sampling and testing were used to investigate the relationship between baseline geochemical and microbial community data and in situ reductive dechlorination rates at a site contaminated with trichloroethene (TCE) and carbon tetrachloride (CTET). Ten monitoring wells were selected to represent conditions along a groundwater flow path from the contaminant source zone to a wetlands groundwater discharge zone. Background ground water samples were analyzed for a suite of geochemical and microbial parameters, and push-pull tests with fluorinated reactive tracers were used to measure in situ reductive dechlorination rates. Geochemical data provided some evidence that reductive dechlorination was occurring at the site, and microbial data confirmed the presence of known dechlorinating organisms as well as sulfate reducers, iron reducers, and methanogens. A principal component analysis identified three groups of wells with similar geochemical and microbial characteristics. Push-pull tests were conducted using trichlorofluoroethene (TCFE) as a reactive tracer for trichloroethene (TCE) and trichlorofluoromethane (TCFM) as a reactive tracer for tetrachloromethane (carbon tetrachloride or CTET). Injected TCFE was transformed in situ to cis- and transdichlorofluoroethene and chlorofluoroethene. In one test, TCFE was completely dechlorinated to fluoroethene. Injected TCFM was transformed in situ to dichlorofluoromethane and chlorofluoromethane. Zero-order TCFE transformation rates ranged from $<0.05$ to $1.00 \mathrm{nM} / \mathrm{hr}(<0.44$ to $8.76 \mu \mathrm{M} / \mathrm{yr})$. TCFE reduction rates were different among the three groups of wells identified by principal component analysis, providing preliminary evidence that geochemical, microbiological, and in situ reductive dechlorination rates may provide complimentary and, perhaps similar, information. A 
WSRC-STI-2006-00340

January 2, 2007

Page 3 of 42

single TCFM transformation rate was estimated as $<0.05 \mathrm{nM} / \mathrm{hr}(0.44 \mu \mathrm{M} / \mathrm{yr})$. This study demonstrated for the first time that push-pull tests with reactive tracers can be used to detect and quantify reductive dechlorination of chlorinated ethenes and ethanes under monitored natural attenuation conditions. 


\section{INTRODUCTION}

Trichloroethene (TCE), tetrachloromethane (carbon tetrachloride, CTET), and related chlorinated ethenes and ethanes are among the most-frequently detected organic contaminants in groundwater. Under anaerobic conditions, TCE and CTET are transformed via reductive dechlorination pathways to produce less-chlorinated products (Ballapragada et al., 1997; de Best, 1997, 1999; Newell et al., 2000; Adamson and Parkin, 2001; Major et al., 2002). However, the rate and extent of reductive dechlorination and the distribution of transformation products are known to vary widely. For example, complete dechlorination of TCE to ethene has been observed at some sites, whereas incomplete transformation has resulted in the accumulation of dichloroethene (DCE) isomers or vinyl chloride (VC) with no ethene production at other sites (Middeldorp et al., 1999).

Reliable information on the occurrence, extent, and rate of reductive dechlorination is particularly important for monitored natural attenuation (MNA) assessments. Currently, environmental assessments utilize a range of techniques to estimate the potential of MNA. These methods include long-term contaminant data supplemented with synoptic geochemical and microbial sampling and numerical modeling to estimate the likelihood that MNA will be successful (see e.g., Wiedemier et al., 1996). Geochemical and microbial indicator data are commonly used to assess whether groundwater conditions are favorable for reductive dechlorination. For example, measurements of electron acceptors (e.g., $\mathrm{O}_{2}, \mathrm{NO}_{3}{ }^{-}$, and $\mathrm{SO}_{4}{ }^{2-}$ ) or reduced metabolic products (e.g., $\mathrm{HS}^{-}, \mathrm{Fe}^{2+}$, $\mathrm{Mn}^{2+}$ ) can be used to detect the activity of anaerobic microorganisms, whereas quantitative polymerase chain reaction (qPCR) can demonstrate the presence of 
WSRC-STI-2006-00340

January 2, 2007

Page 5 of 42

organisms that are known to partially or completely dehalogenate chlorinated ethenes

(Ritalahti et al., 2006).

Critical factors in MNA assessments include demonstrating that a particular contaminant transformation reaction is occurring, and determining the reaction rate. Geochemical and microbial indicator data are often used to provide indirect 'lines of evidence' of transformation processes, but can yield inconclusive or conflicting results. Contaminant transformation rates are often estimated by either fitting transport models to monitoring well data using the transformation rate as an adjustable parameter or by conducting laboratory microcosm experiments. However, the applicability of these estimates to field-scale predictions of contaminant transport is unknown. For example, transformation rates obtained by fitting monitoring well data to the models have a high level of uncertainty because the diagnostic transformation products may be present as cocontaminants. The observed changes in contaminant concentrations attributed to transformation reactions may also result from unrelated physical or chemical processes due to site heterogeneity and sparse monitoring. Moreover, transformation rate estimates obtained from microcosm experiments, which do not always accurately mimic in situ conditions, should be interpreted with caution.. Thus, there is a demand for the development of field methods that verify the biotransformation of contaminants and quantify in situ transformation rates (Madsen, 1991; 1998), especially under MNA conditions, where reaction rates may be slow.

Several previous studies have demonstrated that single-well, push-pull tests are capable of detecting and quantifying a wide range of biotransformation reactions including reductive precipitation of radionuclides (Istok et al., 2004), anaerobic 
WSRC-STI-2006-00340

January 2, 2007

Page 6 of 42

degradation of aromatic hydrocarbons (Reusseur et al., 2002), and aerobic cometabolism of chlorinated ethenes (Kim et al., 2004). Recently, push-pull tests have been used to measure in situ rates of reductive dechlorination of chlorinated ethenes using injected reactive tracers with similar chemical structures and reactivities to the targeted contaminants. These tracer analogs have included trichlorofluoroethene (TCFE) as a reactive tracer for trichloroethene (TCE), cis-dichlorofluoroethene (DCFE) for cis-DCE, chlorofluoroethene (CFE) for VC, and fluoroethene (FE) for ethene (Figure 1) (Hageman et al., 2001; Ennis et al., 2005; Field et al., 2005). Using gas chromatography/mass spectroscopy, it is possible to selectively and sensitively detect and quantify these reactive tracers and their transformation products in the presence of complex contaminant mixtures. Moreover, laboratory and field studies have demonstrated the correlation between the observed transformation pathways and measured rates of these reactive tracers and their targeted contaminants (Vancheeswaran et al., 1999; Hageman et al., 2001 and 2003; Pon and Semprini, 2003; Field et al., 2005; and Ennis et al., 2005). Thus, the observed transformation of an injected fluorinated reactive tracer during a push-pull test provides unambiguous evidence that subsurface conditions are favorable for the reductive dechlorination of the corresponding chlorinated ethene. Push-pull tests have also been shown to be highly reproducible. Over 100 push-pull tests have been conducted at the Oak Ridge Field Research Center in Oak Ridge, Tennessee investigating the microbial reduction of $\mathrm{Tc}$ and $\mathrm{U}$ in various aqueous geochemistries.

Previous studies have used the push-pull test methodology to investigate reductive dechlorination of chlorinated ethenes subsequent to biostimulation with exogenous electron donors (e.g. lactate or $\mathrm{H}_{2}$ ) (see Field et al., 2005). This study represents the first 
WSRC-STI-2006-00340

January 2, 2007

Page 7 of 42

attempt to apply these techniques to a contaminated environment under MNA conditions.

Push-pull tests were conducted in existing monitoring wells using injected TCFE as a reactive tracer for TCE. Because site groundwater also contained trace concentrations of carbon tetrachloride (CTET, tetrachloromethane), we attempted for the first time to measure in situ reductive dechlorination rates for a chlorinated ethane by injecting trichlorofluoromethane (TCFM) as an analog for CTET. Given its similar chemical structure to CTET, we hypothesized that TCFM should be reductively dechlorinated following an analogous pathway (Figure 2). As part of this study, we also collected a comprehensive suite of geochemical and microbial indicator data from the wells prior to the push-pull tests. Although geochemical and microbial data are routinely collected during MNA assessments, this study represents the first attempt to investigate relationships between these data and measured in situ contaminant transformation rates. While fully investigating the relationships among these disparate data types in a systematic and comprehensive way was beyond the scope of this study, the preliminary data reported here will serve as a platform for future research in MNA assessments.

\section{METHODS}

Study Area: Field tests were conducted at The Department of Energy's Savannah River Site (SRS). The C Area Burning/Rubble Pit (CBRP), located near C Reactor, was a shallow, unlined excavation used to dispose of solvents between 1951 and 1973 . Characterization and monitoring activities near CBRP have shown that the groundwater is contaminated with volatile organic compounds, primarily TCE, CTET, and their transformation products (Flach et al., 1999). 
WSRC-STI-2006-00340

January 2, 2007

Page 8 of 42

Test Wells: Within the study area, the principal water-bearing formation is an unconfined aquifer comprised of massive beds of sand and clayey sand containing minor interbeds of clay, which are bounded below by low permeable clay. Groundwater in the unconfined aquifer is recharged by surface infiltration and discharges to wetlands and streams (Flach et al., 1999). A suite of test wells was selected to examine the transformation behavior of injected reactive tracers along groundwater flowpaths from the source zone, through the main plume, to a discharge zone at the Twin Lakes wetlands (Figure 3).

Baseline (Pre-Test) Groundwater Characterization: Groundwater samples were collected from all wells prior to testing using conventional groundwater sampling protocols (i.e. low flow rate purging until the $\mathrm{pH}$, dissolved oxygen, electrical conductivity, and oxidation-reduction potential stabilized, followed by sample collection). Geochemical analyses performed and methods used for baseline characterization are described in Table 1. Microbiological sampling was accomplished by filtering groundwater through a $0.2 \mu \mathrm{m}$ filter and freezing the filter onsite until shipment and processing in the laboratory. Phospholipid fatty acid (PLFA) analysis was performed on the samples according to the methods described by Pinkart et al. (2002). 16S rRNA gene diversity was assessed via denatured gradient gel electrophoresis (DGGE) with band excision and sequencing as described by Peacock et al. (2004). For real-time PCR analyses, samples were extracted using MoBio Laboratories (Solana Beach, CA) Power Soil DNA kits according to the manufacturer's recommendations. Real-time PCR was performed on each sample with oligonucleotides designed to target the region of interest (Suzuki, 2000). For Taqman-based assays, one of the 
WSRC-STI-2006-00340

January 2, 2007

Page 9 of 42

oligonucleotides was a probe containing 6-carboxy-fluorescein (FAM) as a reporter fluorochrome on the 5' end, and N,N,N,N-tetramethyl-6-carboxyrhodamine (TAMRA) as a quencher on the $3^{\prime}$ end. Each $30 \mu 1$ reaction contained $1 \mathrm{X}$ TaqMan Universal PCR Master Mix (Applied Biosystems), forward primer, reverse primer, Taqman probe and DNA template from the extracted samples. The PCR conditions were as follows: 2 min at $50^{\circ} \mathrm{C}$ and $10 \mathrm{~min}$ at $95^{\circ} \mathrm{C}$, followed by 50 cycles of $15 \mathrm{~s}$ at $95^{\circ} \mathrm{C}$ and $1 \mathrm{~min}$ at $58^{\circ} \mathrm{C}$. The PCR reaction was carried out in an ABI Prism 7300 Sequence Detection System (Applied Biosystems, Foster City, CA) (Harms, 2003 and Stultz, 2001). For SYBR green-based assays, real-time PCR was performed on an ABI 7000 Sequence Detection System (Applied Biosystems, Foster City, CA). PCR mixtures contained 1 X Cloned Pfu Buffer (Stratagene, LaJolla, CA), $0.2 \mathrm{mM}$ of each of the four deoxynucleoside triphosphates, SYBR green (diluted 1:30,000; Molecular Probes, Eugene, OR), and 1 U of Pfu Turbo HotStart DNA polymerase (Stratagene, LaJolla, CA). Annealing temperatures, primer concentrations, and $\mathrm{MgCl}_{2}$ concentrations varied and were dependent on the primer sets (Greene, 2003 and Hales, 1996). A calibration curve was obtained via serial dilution of a known concentration of positive control DNA. The CT values obtained from each sample were compared with the standard curve to determine the original sample DNA concentration. $\delta{ }^{13} \mathrm{C}$ values for TCE and DCE were assayed according to methods described in Sherwood-Lollar et al. (2001).

Test Solution Preparation and Injection: Trichlorofluoroethene (TCFE) was obtained from ABCR Chemicals (Karlsruhe, Germany), and trichlorofluoromethane (TCFM) was obtained from SynQuest Laboratories, Inc. (Alachua, FL). Test solutions were prepared by collecting groundwater from each well in a plastic tank, adding sodium bromide as a 
WSRC-STI-2006-00340

conservative tracer, and degassing with nitrogen gas to mix and deoxygenate the test solution prior to injection. Concentrated aqueous solutions of the reactive tracers were stored in collapsible metalized-film (for TCFE) or teflon (for TCFM) gas-sampling bags (Chromatography Research Supplies, Addison, IL) to prevent volatilization losses. For each push-pull test, $\sim 200 \mathrm{~L}$ of test solution were injected into the well using a peristaltic pump. TCFE and TCFM were added by metering the solution from the collapsible bag into the main injection line using a second pump head installed on the peristaltic pump. The chemical composition of the test solution was determined by collecting and analyzing samples during injection.

Transport Tests: Transport tests were conducted in three wells to obtain retardation factors for site-scale modeling and interpreting transformation test data. Test solutions were prepared and injected as described above. Immediately after completion of the injection phase, a peristaltic pump was used to continuously extract groundwater from the test well until $\sim 3$ times the injected volume had been extracted. Sufficient samples were collected during the extraction phase and analyzed to prepare breakthrough curves for all injected tracers and their transformation products. Tests were completed within 4 to 6 hours. Retardation factors were estimated from transport test data using the method of Schroth et al. (2001), which assumes that TCFE and TCFM sorption behavior can be described by linear equilibrium isotherms.

Transformation Tests: Transformation tests were conducted in ten wells. Test solutions were prepared and injected as described above. Samples of the test solution/groundwater mixture were collected approximately once per week for up to 10 weeks following injection. Dilution-adjusted concentrations for the injected reactive 
WSRC-STI-2006-00340

tracers and their transformation products formed in situ were prepared using the "forced mass balance" (FMB) technique developed by Hageman et al. (2003). The FMB technique requires estimates of retardation factors for injected reactive tracers and their transformation products. Retardation factors for TCFE and TCFM were obtained from the transport test data as described above. Retardation factors for TCFE and TCFM transformation products were estimated using the estimated retardation factor for TCFE or TCFM and the octanol:water partition coefficient (Kow) for each compound as follows (using DCFE as an example):

$$
\begin{aligned}
& \mathrm{R}_{\mathrm{TCFE}}=1+\frac{\rho_{\mathrm{b}} \mathrm{K}_{\mathrm{TCFE}}}{\mathrm{n}} \\
& \mathrm{R}_{\mathrm{DCFE}}=1+\frac{\rho_{\mathrm{b}}}{\mathrm{n}} \frac{\mathrm{Kow}_{\mathrm{DCFE}}}{\mathrm{Kow}_{\mathrm{TCFE}}} \mathrm{K}_{\mathrm{TCFE}}
\end{aligned}
$$

where $\mathrm{R}_{\mathrm{TCFE}}$ is the estimated TCFE retardation factor obtained from a transport test, $\mathrm{K}_{\mathrm{TCFE}}$ is the computed sediment:water distribution coefficient for TCFE, $\mathrm{Kow}_{\mathrm{DCFE}}$ and Kow ${ }_{\mathrm{TCFE}}$ are octanol:water partition coefficients and $\mathrm{R}_{\mathrm{DCFE}}$ is the estimated DCFE retardation factor. An analogous procedure was used for all TCFE and TCFM transformation products. Dilution-adjusted concentration profiles were fitted by minimized least squares to obtain in situ transformation rates.

Analytical Methods: Samples for bromide analysis were collected in 15-mL plastic vials. Samples for volatiles analysis including TCFE, TCFM, and their transformation products were collected in 40-mL glass acid-preserved VOA vials without headspace. Samples were stored and shipped on ice until analyzed. Bromide concentrations were determined using a Dionex model DX-120 ion chromatograph equipped with an electrical 
WSRC-STI-2006-00340

conductivity detector and AS14 column. Concentrations of TCFE, DCFE, CFE, TCFM, DCFM, and FM were determined by headspace analysis with gas chromatography/mass spectrometry (GC/MS) consisting of a Hewlett-Packard model 5890 GC equipped with a 5972 series MS detector. Chromatographic separations were performed on a Supelco (30 $\mathrm{m} \times 0.32 \mathrm{~mm} \times 4 \mu \mathrm{m}) \mathrm{SPD}-1$ column. The fluorinated transformation products were positively identified by comparing their spectra, which were obtained by operating the MS in scan mode, to published spectra. The MS was operated in selected ion monitoring mode for quantitation. 1-Chloropropane and 1-chlorobutane were used as internal standards for gas chromatography.

\section{RESULTS and DISCUSSION}

\section{Groundwater Characterization:}

TCE was detected in every monitoring well except well CRP-41A. TCE concentrations ranged from $3100 \mu \mathrm{g} / \mathrm{L}$ in CRP-20CL (near the source and in the plume) to $30 \mu \mathrm{g} / \mathrm{L}$ in CRP-44B (the wetland groundwater discharge area) (Table 2). Although cis-1,2-DCE was detected in every monitoring well except CRP-41A, trans-1,2-DCE was only detected in five wetland wells. Vinyl chloride (VC) was only detected in wetland well CRP-48B. Surprisingly, ethene was detected in all of the wells sampled except CRP-42B. The highest ethene concentrations were detected in source well CRP-3D, plume well CRP-18D, and wetland well CRP-48B. Collectively, the chlorinated ethene data provide evidence that reductive dechlorination is occurring at the site, as demonstrated by the detection of cis- and trans-1,2-DCE in the wetland wells. The detection of VC in one wetland well, which also had the highest measured ethene 
WSRC-STI-2006-00340

concentration, suggests that indigenous microorganisms may have the ability to completely transform TCE to ethene. However, this interpretation is confounded by the widespread distribution of trace ethene in wells without VC .

Stable isotope data for wells CRP-3D, 18D, 29CL, 41A, and 41B had $\delta^{13} \mathrm{C}$ values of $\sim-26$ to $-28 \%$ for TCE and -21 to $-23 \%$ for cis-DCE. More positive (i.e. less negative) $\delta^{13} \mathrm{C}$ values for TCE and more negative $\delta^{13} \mathrm{C}$ values for cis-DCE were obtained for wetland wells CRP-42A, 42B, 43B, 44B. The only positive $\delta^{13} \mathrm{C}$ value for TCE (1 \%o) occurred in wetland well CRP-44B. In laboratory studies, reductive dechlorination of TCE has resulted in $\delta^{13} \mathrm{C}$ values for TCE as large as $14 \%$ (Bloom et al. 2000; Sherwood Lollar et al. 1999), although field values are usually much lower (Sherwood Lollar et al., 2001). The wetland well data demonstrated more positive $\delta^{13} \mathrm{C}$ values for TCE, suggesting microbial preference for the lighter isotope and thus evidence for TCE reductive dechlorination.. These findings are also consistent with the higher measured concentrations of cis- and trans-DCE, VC, and ethene in those wells.

Carbon tetrachloride was detected above trace levels in wells CRP-20CL and CRP-41A. Chloroform was only detected in these wells and well CRP-3D. Although chloroform is a known reductive dechlorination product of anaerobic CTET transformation (Figure 1), it is also a common co-contaminant with carbon tetrachloride. Therefore, its presence does not provide unequivocal evidence for ongoing carbon tetrachloride reductive dechlorination.

The conclusion that conditions in the wetland wells are favorable for the reductive dechlorination of chlorinated solvents was also supported by geochemical data. However, not all of the measured parameters yielded consistent results (Table 2). For example, 
WSRC-STI-2006-00340

January 2, 2007

Page 14 of 42

although reductive dechlorination often proceeds under sulfate- or iron-reducing conditions, dissolved oxygen was detected in all wells, with concentrations ranging from 1.5 to $8.2 \mathrm{mg} / \mathrm{L}$. Nitrate was detected in every well except CRP-43D, and nitrite was detected in wells CRP-3D, 41A, 43B and 44B, suggesting that denitrification is an important microbial process. Sulfate but not sulfide was detected at low levels throughout the site, suggesting that sulfate reduction may be a relatively minor process. $\mathrm{Fe}^{2+}$ was detected in three wetland wells (CRP-41A, 41B and 48B), indicative of iron reduction. Wells CRP-41A, 41B and 48B also contained the highest methane concentrations. Fermentation products were also detected in several wells. Acetate was detected at trace concentrations $(<1 \mathrm{mg} / \mathrm{L})$ in every well except CRP-18D and 42B, and the highest concentration occurred in wetland well CRP-44B $(2.25 \mathrm{mg} / \mathrm{L})$. Lactate was detected in wells CRP-20CL and 44B, and propionate was detected in wells CRP-41A and 44B. Curiously, soluble organic carbon was not detected in any well. Oxygen reduction potential (ORP) values were highly variable and ranged from -125.3 to 135 $\mathrm{mV}$, and the most negative ORP values occurred in two wetland wells.

Microbial data provided additional evidence of increased microbial activity in wetland wells (Table 3). Biomass estimates derived from Eubacterial Q-PCR results were highest in wetland well CRP-43B $\left(\sim 10^{6}\right.$ copies $\left./ \mathrm{mL}\right)$ and lowest in plume well CRP$18 \mathrm{D}\left(\sim 10^{3}\right.$ copies $\left./ \mathrm{mL}\right)$. Q-PCR results were generally consistent with trends in microbial activity inferred from geochemical data. The highest numbers of iron- and sulfatereducing bacteria were detected in the wetland wells, and methanogens were detected in all wells except well CRP-18D. Dehalococcoides spp. (DHC), which are capable of complete dechlorination of TCE, were detected in six wells. The highest abundance of 
WSRC-STI-2006-00340

DHC was detected in well CRP-48B, which also had the highest VC and ethene concentrations.

Biomass estimates derived from phospholipid fatty acids (PLFA) analysis ranged from below detection to $\sim 10^{7}$ per $\mathrm{mL}$, with the largest value in well CRP-44B. PLFA profiles showed that the microbial community compositions varied considerably among the wells. In three of the four wells with the lowest biomass (CRP-3D, 20 CL, 41B, and 41A), only monoenoic PLFA and normal saturated PLFA were detected, indicating the presence of relatively simple microbial communities. Monoenoic PLFA are indicative of Gram negative Proteobacteria. Normal saturated PLFA are general biomarkers found in all living organisms, and therefore, their presence does not provide significant insight into the microbial community composition. Well CRP-48B had a notable proportion of eukaryotic biomarkers (polyenoic PLFA) but primarily contained normal saturated PLFA. Eukaryotic biomarkers were detected in five of the wells, in proportions ranging from $\sim 1$ to $12 \%$, with the highest proportion in well CRP-48B. The specific biomarker detected in these wells was $18: 2 \omega 6$, which is often attributed to the presence of fungi (Pinkart et al., 2002). Three wells contained biomarkers indicative of the presence of anaerobes, and these wells also had the highest biomass estimates. Well CRP-42A had a large proportion of mid-chain-branched saturated PLFA $(\sim 30 \%)$, which are attributed to the presence of sulfate-reducing bacteria and/or Actinomycetes. Wells CRP-44B and CRP-43B had notable proportions of Firmicutes (shown by terminally-branched saturated PLFA) ( 6\% and $\sim 2 \%$, respectively). Firmicutes include Clostridia/Bacteroides-like fermenting bacteria. The presence of fermenting bacteria is important at locations 
WSRC-STI-2006-00340

contaminated with chlorinated solvents because fermenters can provide the $\mathrm{H}_{2}$ necessary for reductive dechlorination.

The DGGE profiles contained numerous bands, several of which were faint (Figure 4). Several prominent bands were excised and subjected to PCR and sequence analysis to identify the closest known bacterial genus based on sequence similarity. Phylogenetic affiliations were determined by comparing the sample 16S rRNA gene sequences to known bacterial sequences in the Ribosomal Database Project (RDP) and/or the National Center for Biotechnology Information database (GenBank). For each sequenced PCR product, the closest described match is reported (Table 4).

A principal component analysis (PCA) of the geochemical and microbial data was used to investigate overall patterns of similarity among the wells (Figure 5). The results show that the wells can be separated into three distinct groups. The first group contained wells CRP-3D, 20CL, and 18D, which had relatively higher concentrations of dissolved oxygen, nitrate and TCE, and relatively lower concentrations of less-chlorinated ethenes. Group 2 contained wells CRP-42A, 43B, 44B and possibly CRP-42B, and had higher concentrations of $\mathrm{CO}_{2}$, methane, trans-1,2-DCE, acetate, mid-chain-branched saturated PLFA, terminally-branched saturated PLFA, and methanogens. Group 3 contained wells CRP-41A, 41B, and 48A, and exhibited relatively higher concentrations of $\mathrm{Fe}^{2+}, \mathrm{VC}$, and ethene, as well as higher abundances of Dehalococcoides spp.

Transport Tests: Extraction phase breakthrough curves for TCFE and TCFM exhibited slightly larger apparent dispersion compared to the coinjected $\mathrm{Br}^{-}$tracer, which is attributed to sorption (Figure 6). Model fits obtained using the method of Schroth et al. (2001) were generally good, and the estimated retardation factors for TCFE were 
WSRC-STI-2006-00340

between 1.1 and 2.5, with an average of 1.9 (Table 5). Estimated retardation factors for TCFM were somewhat larger, ranging from 1.9 to 5.1, with an average of 3.3 (Table 5). These results were expected because TCFM is more hydrophobic, having a lower aqueous solubility and higher octanol:water partition coefficient than TCFE. The method of Schroth et al. (2001) also provides estimates for aquifer dispersivity, and these values ranged from 0.5 to $2.0 \mathrm{~cm}$, with an average of $1.1 \mathrm{~cm}$ (Table 5).

Transformation Tests: In situ transformation of injected TCFE was observed in wells CRP-3D, 18D, 41A, 41B, 22CL, and 48A. In situ transformation of injected TCFM was also observed in well CRP-3D. Unequivocal evidence that aquifer conditions support the reductive dechlorination of TCFE and TCFM (and, by analogy, TCE and CTET) was demonstrated by the detection of diagnostic reductive dechlorination products from these tracers including cis- and trans-DCFE, CFE, FE, DCFM, and CFM. However, in most tests FE was not detected (see below), and our analytical method was unable to quantify FM. In this test we were only able to monitor the reductive daughter products of TCFE and TCFM. Doubtless there may be other mechanisms at work in regards to the attenuation of the reactive tracers (e.g. oxidation or mineralization). We were not able to measure these processes, but using the mass balance approach that the push-pull affords we could quantify the reductive processes.

In well CRP-41B, injected TCFE was transformed to DCFE and CFE during the $\sim 1,800$-hour duration test (Figure 7). As in all tests, transformation product concentrations were very low, and only a small fraction of the injected TCFE was transformed to less-chlorinated products. For this test, the maximum DCFE concentration after dilution-adjustment was only $\sim 270 \mathrm{nM}$, which was $\sim 1 \%$ of the 
WSRC-STI-2006-00340

injected TCFE concentration (Figure 7). The estimated TCFE transformation rate was 0.001/day. FE was not detected, which may be due to an inability of the indigenous microorganisms to dechlorinate CFE or limitations of the methodology in measuring extremely low transformation rates. Variable groundwater flow velocities in the test wells resulted in variable dilution rates for injected reactive tracers. If transformation proceeds slowly, then the test solution may be transported downgradient from the well before the terminal transformation products are detected. For this reason Ennis et al. (2005) proposed the use of injected CFE to improve the sensitivity of detecting the transformation of CFE to FE.

Transformation of TCFE to DCFE, CFE, and FE was observed in well CRP-48A (Figure 8). The detection of FE is significant and provides definitive evidence that indigenous microorganisms at this location have the metabolic capability to completely dechlorinate TCFE, and by analogy, TCE. The estimated TCFE transformation rate was 0.002/day (Table 6).

Measured reductive dechlorination rates for TCFE across all tests were highly variable, ranging from $<0.0005$ to $0.002 /$ day (Table 6). These rates are orders of magnitude slower than TCFE transformation rates (0.05 to $1.6 /$ day) reported in previous field tests by Hageman et al. (2001, 2003) and Field et al. (2005). The slower rates in this study may be attributed to differences in aquifer and experimental conditions compared to the other field sites. The Hageman et al. (2001) study was conducted under aquifer conditions with significantly higher concentrations of TCE (approaching 4000 $\mu \mathrm{M})$ and other chlorinated solvents, as well as a wide range of organic contaminants (esp. petroleum hydrocarbons) which could serve as electron donors during reductive 
WSRC-STI-2006-00340

dechlorination. In contrast, the TCE concentrations in the aquifer at the SRS site were very low, and aqueous concentrations of potential electron donors were very low (Table 2). More importantly, in the Hageman et al. (2003) and Field et al. (2005) studies, the microbial activity was stimulated via fumarate, hydrogen, and lactate amendments to increase reductive dechlorination rates.

These results represent the first in situ measurements of TCFE reductive dechlorination rates under low chlorinated solvent concentrations and low microbial activity conditions. These aquifer conditions are typical of many dilute contaminant plumes for which MNA may be an appropriate remedy. In practice, the rate measurements (and retardation factors obtained from transport tests) can be used as inputs to site-scale numerical flow and transport models, which would then be used to evaluate the ability of MNA to meet site cleanup goals. The sensitivity of the push-pull tests are dependent on the analytical methods used to assess the daughter products of the reactive tracers.

Interestingly, measured TCFE reductive dechlorination rates were in qualitative agreement with the results of the principal component analysis of geochemical and microbial indicator data (Figure 8). Wells in Groups 1 and 2 had the lowest estimated TCFE transformation rates ( $<=0.001 /$ day), while wells in Group 3 had the highest transformation rates $(\sim 0.002 /$ day $)$. Although a larger data set would be needed to evaluate the statistical significance of this correlation, the results suggest that it may be possible to evaluate relationships among geochemical and microbial indicator and reductive dechlorination rates. 
TCFM was injected in a single test in source well CRP-3D, and unequivocal evidence for in situ TCFM transformation was demonstrated by the detection of the diagnostic transformation products DCFM and CFM. FM could not be resolved by our analytical method (Figure 9). The maximum dilution-adjusted concentration for DCFM was $\sim 0.9 \mu \mathrm{M}$, which is $\sim 5 \%$ of the injected TCFM concentration. The estimated TCFM transformation rate was 0.001 /day.

\section{CONCLUSIONS}

This study presented the first successful detection and quantification of in situ reductive dechlorination activity for injected TCFE in the absence of exogenous donors to stimulate microbial activity in the subsurface. Because the test solutions were prepared with site groundwater and interrogated a large volume of the subsurface $(\sim 0.1$ to $0.3 \mathrm{~m}^{3}$ ), they are reasonably representative of the metabolic capabilities of indigenous microorganisms under the specific biogeochemical conditions existing in this aquifer. This study also showed that reductive dechlorination of TCFM can be detected and suggests that the suitability of this compound as a reactive tracer to monitor the reductive dechlorination of carbon tetrachloride (CTET) should be explored in additional laboratory and field studies. An important first step would be to investigate the ability of known dechlorinating organisms to transform TCFM and to compare transformation rates for TCFM and CTET under similar conditions.

In situ monitored natural attenuation or enhanced attenuation are often the most cost-effective methods of remediating groundwater contaminated with low concentrations of chlorinated solvents. The key to demonstrating the potential efficacy of monitored 
WSRC-STI-2006-00340

natural attenuation (MNA) at a site is establishing cause-and-effect relationships, which provide direct evidence that biodegradative processes are either occurring or that these processes can be enhanced. The use of reactive tracers like TCFE and TCFM provides direct and unequivocal evidence that biotransformation is occurring in situ and should be a useful approach for performing monitored natural attenuation assessments at chlorinated solvent sites.

\section{ACKNOWLEDGEMENTS}

This work was sponsored by the U. S. Department of Energy Office of Cleanup Technologies and administered by the Savannah River Operations Office (Contract No. DE-AC09-96SR18500). This project is one of the 14 research studies selected for the Department of Energy (DOE) Monitored Natural Attenuation/Enhanced Attenuation (MNA/EA) project (http://www.srs.gov/general/scitech/srtc/srtchtm/newsjan5.pdf). Technical direction and management were provided by the Savannah River National Laboratory.

\section{LITERATURE CITED}

Adamson, D.T. and G. F. Parkin. 2001. Product distribution during transformation of multiple contaminants by a high-rate, tetrachloroethene-dechlorinating enrichment culture. Biodegradation. 12(5):337 - 348 .

Ballapragada, B.S., H.D. Stensel, J.A. Puhakka, and J.F. Ferguson. 1997. Effect of hydrogen on reductive dechlorination of chlorinated ethenes. Environ. Sci. Technol. 31(6):1728 - 1734. 
Bloom, Y., R. Aravena, D. Hunkeler, E. Edwards, and S.K. Frape. 2000. Stable carbon isotope fractionation of trichloroethene during microbially-mediated reductive dechlorination. Environ. Sci. Technol. 34: 2768-2772.

de Best, J.H., E. Salminen, H. J. Doddema, D. B. Janssen, and W. Harder. 1997. Transformation of carbon tetrachloride under sulfate reducing conditions. Biodegradation. 8(6):429-436

de Best, J. H., P. Hunneman, H. J. Doddema, D. B. Janssen, and W. Harder. 1999. Transformation of carbon tetrachloride in an anaerobic packed-bed reactor without addition of another electron donor. Biodegradation. 10(4): 287 - 295.

Ennis, E., R. Reed, M. Dolan, L. Semprini, J.D. Istok, and J.A. Field. 2005. Reductive dechlorination of the vinyl chloride surrogate chlorofluoroethene in TCEcontaminated groundwater. Environ. Sci. Technol. 39: 6777-6785.

Field, J.A., J.D. Istok, L. Semprini, P. Bennett, and T. Buscheck. 2005. Trichlorofluoroethene: A reactive tracer for evaluating in situ trichloroethene remediation. Ground Water Monitoring \& Remediation. 25: 1-10.

Flach, G.P., M.K. Harris, R.A. Hiergesell, A.D. Smits, and K.L. Hawkins. 1999. Hydrogeological Analysis and Groundwater Flow for C-Reactor Area with Contaminant Transport for C-Reactor Seepage Basins (CRSB) and C-Area Burning/Rubble Pit (CBRP)(U) Westinghouse Savannah River Company Savannah River Site, WSRC-TR-99-00310.

Greene, E.A., C. Hubert, M. Nemati, G. E. Jenneman and G. Voordouw. 2003. Nitrite reductase activity of sulphate-reducing bacteria prevents their inhibition by nitratereducing, sulphide-oxidizing bacteria. Environ. Microbiol. 5(7): 607-617. 
WSRC-STI-2006-00340

Hageman, K. J., J.A. Field, J.D. Istok, and M.H. Schroth. 2003. Forced mass balance technique for estimating in situ transformation rates of sorbing solutes in groundwater. Environ. Sci. Technol. 37: 3920-3925.

Hageman, K.J., J.D. Istok, T.E. Buscheck, and L. Semprini. 2001. In situ anaerobic transformation of trichlorofluoroethene in trichloroethene-contaminated groundwater. Environ. Sci. Technol. 35:1729-1735.

Hales, B.A., C. Edwards, D.A. Ritchie, G. Hall, R.W. Pickup, and J.R. Saunders. 1996. Isolation and identification of methanogen-specific DNA from blanket bog peat by PCR amplification and sequence analysis. Appl. Environ. Microbiol. 62:668-675. Harms, G., A.C. Layton, H.M. Dionisi, I.R. Gregory, V.M. Garrett, S.A.Hawkins, K.G. Robinson, and G.S. Sayler. 2003. Real-time PCR quantification of nitrifying bacteria in a municipal wastewater treatment plant. Environ. Sci. Technol. 37:343351.

Istok, J.D., J.S. Senko, L. R. Krumholz, D. Watson, M.-A. Bogle, A. Peacock, Y-J. Chang, and D.C. White. 2004. In situ bio-reduction of technetium and uranium in a nitrate-contaminated aquifer. Environ. Sci.Technol. 38:468-475.

Kim, Y., J.D. Istok, and L. Semprini. 2004. Push-pull tests for assessing in situ aerobic cometabolism. Ground Water. 42:329-337.

Madsen, E.L. 1991. Determining in situ biodegradation: Facts and challenges. Environ. Sci. Technol. 25:1663-1673.

Madsen, E.L. 1998. Epistemology of environmental microbiology. Environ. Sci.Technol. 32: $429-439$. 
Major, D.W., M.L. McMaster, E.E. Cox, E.A. Edwards, S.M. Dworatzek, E.R. Hendrickson, M.G. Starr, J.A. Payne, and L.W. Buonanici. 2002. Field demonstration of successful bioaugmentation to achieve dechlorination of tetrachloroethene to ethene. Environ. Sci. Technol. 36:5105-5116.

Middeldorp, P.J.M., M.L.G.C. Luijten, B.A. van de Pas, M.H.A. van Eekert, S.W.M. Kengen, G. Schraa, and A.J.M. Stams. 1999. Anaerobic microbial reductive dehalogenation of chlorinated ethenes. Bioremediation Journal. 3:151-169.

Newell, C.J, P.E. Haas, J.B. Hughes, and T. Khan. 2000. Results from two direct hydrogen delivery field tests for enhanced dechlorination. 2nd International Conference on Remediation of Chlorinated and Recalcitrant Compounds, May 2225, 2000, Monterey, CA.

Park, E. and J.C. Parker. 2005. Evaluation of an upscaled model for DNAPL dissolution kinetics in heterogeneous aquifers. Adv. Water Res.. 28:1280-1291.

Unlu, K., J. C. Parker, and P. K. Chong. 1995. A comparison of three uncertainty analysis methods to assess groundwater impacts from land-disposed waste. Hydrogeology Journal. 3(2):4-18.

Parker, J. C.. 2003. Physical processes affecting natural depletion of volatile chemicals in soil and groundwater. Vadose Zone Journal. 2:222-230..

Parker, J.C. and E. Park. 2004. Field-scale DNAPL dissolution kinetics in heterogeneous aquifers. Water Resources Research. 40: CiteID W05109, doi:10.1029/2003WR002807. 
Pinkart, H.C., D.B. Ringelberg, Y.M. Piceno, S.J. MacNaughton, and D.C. White. 2002. Biochemical Approaches to Biomass Measurements and Community Structure Analysis. In Manual of Environmental Microbiology Second Edition, C.J. Hurst, R.L. Crawford, G.R. Knudsen, M.J. McInerny and L.D. Stetzenbach Eds. ASM Press, Washington, DC. Pp 101-113.

Peacock, A.D., Y-J. Chang, J. D. Istok, L. Krumholz, R. Geyer, B. Kinsall, D. Watson, K.L. Sublette, and D.C. White. Utilization of microbial biofilms as monitors of bioremediation. Microbial Ecology. 47:284-292.

Pon, G. and L. Semprini. 2004. Anaerobic reductive dechlorination of 1-chloro-1fluoroethene to track the transformation of vinyl chloride. Environ. Sci. Technol. 38: $6803-6808$.

Reusser, D.E., J.D. Istok, H.R. Beller, and J.A. Field. 2002. In situ transformation of deuterated toluene and xylene to benzylsuccinic acid analogues in BTEXcontaminated aquifers. Environ. Sci. Technol. 36:4127-4134.

Ritalahti, K. M., B.K. Amos, Y. Sung, Q.Wu, S.S. Koenigsberg, and F.E. Löffler. 2006. Quantitative PCR targeting 16S rRNA and reductive dehalogenase genes simultaneously monitors multiple Dehalococcoides strains. Appl. Environ. Microbiol. 72(4): 2765-2774.

Schroth, M.H., J.D. Istok, and R. Haggerty. 2001. In-situ evaluation of solute retardation using single-well push-pull tests. Adv. Water Res. 24: 105-117. 
WSRC-STI-2006-00340

Sherwood, L. B., G.F. Slater, J. Ahad, B. Sleep, J. Spivack, M. Brennan, and P.

MacKenzie. 1999. Contrasting carbon isotope fractionation during biodegradation of trichloroethylene and toluene: Implications for intrinsic bioremediation. Org. Geochem. 30:813-820.

Sherwood Lollar, B., G.F. Slater, B. Sleep, M. Witt, G.M. Klecka, M. Harkness, and J. Spivack. 2001. Stable carbon isotope evidence for intrinsic bioremediation of tetrachloroethene and trichloroethene at Area 6, Dover Air Force Base. J. Environ. Sci. Technol. 35:261-269.

Stults, J.R., O. Snoeyenobos-West, B. Methe, D.R Lovley, and D.P. Chandler. 2001. Application of the fluorogenic exonuclease assay (TaqMan) for quantitative ribosomal DNA and rRNA analysis in sediments. Appl. Environ. Microbiol. 67(6):2781-2789.

Suzuki, M.T., L.T. Taylor, and E.F. Delong. 2000. Quantitative analysis of small-subunit rRNA genes in mixed microbial populations via nuclease assays. Appl. Environ. Microbiol. 66(11):4605-4614.

Vancheeswaran, S., M.R. Hyman, and L. Semprini. 1999. Anaerobic bio-transformation of trichlorofluroethene (TCFE) in groundwater-microcosms. Environ. Sci. Technol. 33(12): 2040-2045.

Wiedemier, T.H., M.A. Swanson, J.T. Wilson, D.H. Kampbell, R.N. Miller, and J.E. Hansen. 1996. Approximation of biodegradation rate constants for nonaqueous hydrocarbons (BTEX) in ground water. Ground Water Monitoring \& Remediation. 16(3):186-1. 
WSRC-STI-2006-00340

January 2, 2007

Page 27 of 42

Table 1. Geochemical analyses and methodologies.

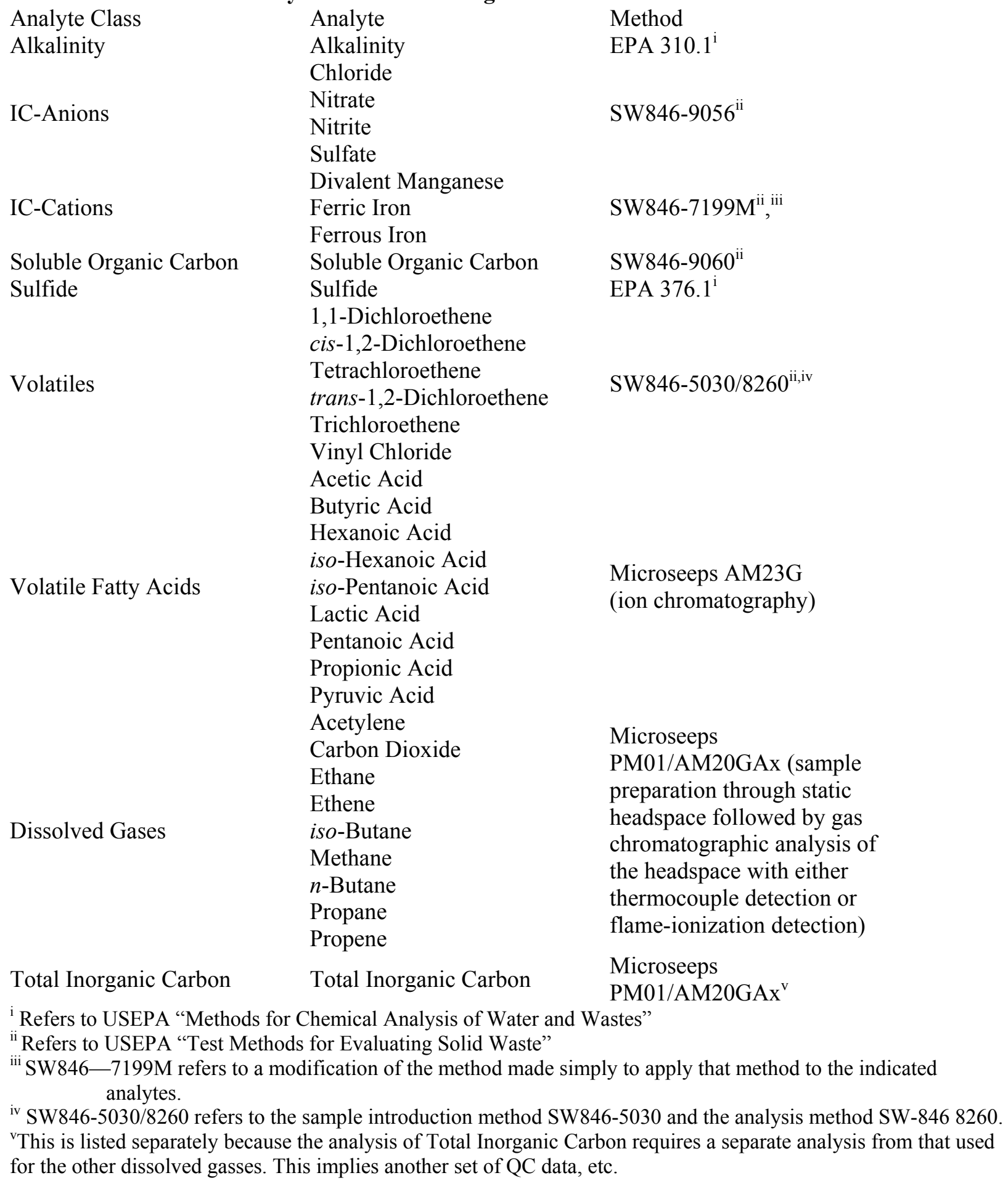




\begin{tabular}{|c|c|c|c|c|c|c|c|c|c|c|}
\hline \multirow{2}{*}{$\begin{array}{l}\text { Sample } \\
\text { Temperature }{ }^{\circ} \mathrm{C}\end{array}$} & \multirow{2}{*}{\begin{tabular}{r|}
$\begin{array}{r}\text { Source } \\
\text { CRP-3D }\end{array}$ \\
17.6
\end{tabular}} & \multicolumn{2}{|c|}{\begin{tabular}{|c|} 
Plume \\
CRP-18D CRP-20CL \\
\end{tabular}} & \multirow{2}{*}{$\begin{array}{r}\text { CRP-41A } \\
15.8\end{array}$} & \multirow{2}{*}{$\begin{array}{r}\text { CRP-41B } \\
16.9\end{array}$} & \multirow{2}{*}{$\begin{array}{r}\text { CRP-42A } \\
15.2\end{array}$} & \multirow{2}{*}{\begin{tabular}{r}
\multicolumn{1}{c}{$\begin{array}{c}\text { Buffer } \\
\text { CRP-42B }\end{array}$} \\
16.6
\end{tabular}} & \multirow{2}{*}{$\begin{array}{r}\text { CRP-43B } \\
14.9\end{array}$} & \multirow{2}{*}{$\begin{array}{r}\text { CRP-44B } \\
14.9\end{array}$} & \multirow{2}{*}{$\frac{\text { CRP-48B }}{15.5}$} \\
\hline & & 17.5 & 19.8 & & & & & & & \\
\hline $\mathrm{pH}$ & 5.0 & 6.2 & 5.0 & 6.2 & 6.6 & 4.8 & 4.4 & 5.1 & 4.9 & 6.2 \\
\hline Oxygen reducing potential (n) & 100 & 81 & 135 & -80 & -125 & 74 & 101 & 75 & 30 & -77 \\
\hline Electrical conductivity & 38 & 48 & 26 & 53 & 52 & 40 & 21 & 13 & 20 & 56 \\
\hline Oxygen mg/L & 8.2 & 8.0 & 2.8 & 2.1 & 1.5 & 5.8 & 4.6 & 4.5 & 1.7 & 1.8 \\
\hline $\mathrm{NO}_{3}^{-} \mathrm{mg} / \mathrm{L}$ & 4.0 & 3.4 & 4.2 & 1.0 & 1.0 & 1.0 & 1.3 & $N D$ & 1.0 & 1.0 \\
\hline $\mathrm{NO}_{2}^{-} \mathrm{mg} / \mathrm{L}$ & 0.53 & $N D$ & ND & 0.53 & $N D$ & $N D$ & $N D$ & 0.53 & 0.53 & $N D$ \\
\hline $\mathrm{SO}_{4}{ }^{2-} \mathrm{mg} / \mathrm{L}$ & 3.3 & 3.8 & 3.2 & 3.5 & 3.2 & 9.7 & 5.1 & 3.6 & 3.3 & 3.5 \\
\hline $\mathrm{HS}^{-} \mathrm{mg} / \mathrm{L}$ & $N D$ & $N D$ & $N D$ & $N D$ & $N D$ & $N D$ & $N D$ & $N D$ & $N D$ & $N D$ \\
\hline $\mathrm{Fe}^{2+} \mathrm{mg} / \mathrm{L}$ & $N D$ & $N D$ & $N D$ & 13 & 13 & $N D$ & $N D$ & $N D$ & $N D$ & 13 \\
\hline Methane ug/L & 0.24 & 0.14 & 170 & 0.92 & 0.38 & 4.6 & 1.8 & 130 & 250 & 130 \\
\hline Hydrogen & ND & $N D$ & 99 & 7.6 & 0.45 & 0.97 & 0.39 & $N D$ & 2.7 & 1.1 \\
\hline TIC mg/L & 51 & 90 & 110 & 97 & 86 & 230 & 57 & 100 & 200 & 96 \\
\hline TCE ug/L & 220 & 220 & 3100 & $N D$ & 570 & 440 & 530 & 87 & 30 & 280 \\
\hline 1,1-DCE ug/L & $N D$ & $N D$ & $N D$ & $N D$ & $N D$ & $N D$ & $N D$ & $N D$ & $N D$ & $N D$ \\
\hline cis-1,2-DCE ug/L & 58 & 17 & 78 & $N D$ & 21 & 200 & 230 & 210 & 400 & 600 \\
\hline trans-1,2-DCE ug/L & $N D$ & $N D$ & $N D$ & $N D$ & $N D$ & 9.9 & 12 & 8.9 & 21 & 18 \\
\hline VC ug/L & $N D$ & $N D$ & $N D$ & $N D$ & $N D$ & $N D$ & ND & $N D$ & $N D$ & 14 \\
\hline Ethene ng/L & 430 & 160 & 9.8 & 10 & 6.2 & 5.4 & $N D$ & 30 & 7.5 & 4800 \\
\hline Acetic Acid mg/L & 0.079 & $N D$ & 0.098 & 0.38 & 0.089 & 0.477 & ND & 0.095 & 2.25 & 0.092 \\
\hline Carbon Dioxide mg/L & 18 & 16 & 26 & 6.2 & 5.9 & 73 & 46 & 33 & 44 & 10 \\
\hline Ethane $\mathrm{ng} / \mathrm{L}$ & 190 & 50 & $N D$ & $N D$ & $N D$ & $N D$ & $N D$ & $N D$ & $N D$ & 210 \\
\hline Lactic Acid and HIBA mg/L & $N D$ & $N D$ & 0.334 & $N D$ & $N D$ & $N D$ & $N D$ & $N D$ & 0.027 & $N D$ \\
\hline Propionic acid mg/L & $N D$ & $N D$ & $N D$ & 0.122 & $N D$ & $N D$ & $N D$ & $N D$ & 0.146 & $N D$ \\
\hline
\end{tabular}


Table 3. Results of microbiological characterization

\begin{tabular}{|c|c|c|c|c|c|c|c|c|c|c|}
\hline \multirow[b]{2}{*}{ qPCR (copies $/ \mathrm{mL}$ ) } & \multirow{2}{*}{$\begin{array}{l}\text { Source } \\
\text { CRP-3D }\end{array}$} & \multicolumn{2}{|c|}{ Plume } & \multirow[b]{2}{*}{ CRP-41A } & \multirow[b]{2}{*}{ CRP-41B } & \multirow[b]{2}{*}{ CRP-42A } & \multirow{2}{*}{$\begin{array}{r}\text { Buffer } \\
\text { CRP-42B }\end{array}$} & \multirow[b]{2}{*}{ CRP-43B } & \multirow[b]{2}{*}{ CRP-44B } & \multirow[b]{2}{*}{ CRP-48B } \\
\hline & & CRP-18D & CRP-20CL & & & & & & & \\
\hline Eubacteria16S & $1.84 \mathrm{E}+06$ & $2.03 \mathrm{E}+03$ & $4.96 \mathrm{E}+04$ & $4.81 \mathrm{E}+06$ & $1.57 \mathrm{E}+06$ & $2.02 \mathrm{E}+06$ & $2.10 \mathrm{E}+06$ & $6.98 \mathrm{E}+06$ & $5.86 \mathrm{E}+03$ & $4.05 \mathrm{E}+05$ \\
\hline Methanogens & $3.94 \mathrm{E}+03$ & $N D$ & $9.05 E+00$ & $4.48 E+04$ & $2.47 E+04$ & $2.24 \mathrm{E}+05$ & $5.67 \mathrm{E}+04$ & $1.00 \mathrm{E}+05$ & $1.95 \mathrm{E}+03$ & $3.85 E+04$ \\
\hline Iron reducing bacteria/sulfate reducing bacteria & $2.26 \mathrm{E}+01$ & ND & $1.00 \mathrm{E}+00$ & $6.80 E+05$ & $6.26 \mathrm{E}+03$ & $2.60 \mathrm{E}+03$ & $7.72 \mathrm{E}+02$ & $2.50 E+04$ & $N D$ & $6.61 \mathrm{E}+02$ \\
\hline Dehalococcoides ethenogenes & $5.01 \mathrm{E}+00$ & ND & $N D$ & $N D$ & $1.61 \mathrm{E}+01$ & $1.24 \mathrm{E}+00$ & $2.43 \mathrm{E}+01$ & $2.61 \mathrm{E}+01$ & ND & $3.38 E+03$ \\
\hline \multicolumn{4}{|c|}{$\begin{array}{l}\text { DGGE (X = Detected; NS = Not sequenced; } \% \text { match }) \\
\text { Unique }\end{array}$} & & & & & $\mathbf{x}$ & & \\
\hline NS & & & & & & $\mathbf{X}$ & & $\mathbf{X}$ & & \\
\hline Deinococcus (87 \%) & & & & & & & & $\mathbf{X}$ & & \\
\hline Unc. AY510168 (85 \%) & & & & & & & & $\mathbf{x}$ & & \\
\hline Pseudomonas (87 \%) & & & & $\mathbf{X}$ & & & & $\mathbf{X}$ & & \\
\hline Unc. AY093473 (89 \%) & & & $\mathbf{x}$ & $\mathbf{x}$ & $\mathbf{x}$ & $\mathbf{x}$ & & & & $\mathbf{x}$ \\
\hline Erythrobacter (97\%) & $\mathbf{X}$ & & & & & & & & & \\
\hline Sulfuricurvum (97\%) & & & & $\mathbf{x}$ & $\mathbf{x}$ & & $\mathbf{x}$ & $\mathbf{x}$ & & $\mathbf{x}$ \\
\hline Rhodoferax (89 \%) & & & & $\mathbf{x}$ & & & & & & $\mathbf{X}$ \\
\hline NS & & & & & $\mathbf{x}$ & & & & & \\
\hline Rhodoferax (100 \%) & & & & $\mathbf{X}$ & & & & $\mathbf{X}$ & & \\
\hline Propionovibrio (81%) & & & & $\mathbf{X}$ & & & & & & \\
\hline Acidobacterium (69 \%) & & & & & & & & & & $\mathbf{x}$ \\
\hline Ralstonia (96 \%) & $\mathbf{X}$ & & & & & & & & & \\
\hline Propionovibrio (94 \%) & & & & & $\mathbf{X}$ & & & & & \\
\hline Beijerinckia (93 \%) & & & & $\mathbf{x}$ & & $\mathbf{x}$ & $\mathbf{x}$ & & & \\
\hline Pelistega (82 \%) & $\mathbf{X}$ & & & & & & $\mathrm{x}$ & & & \\
\hline NS & & & & & & $\mathbf{x}$ & & & & \\
\hline NS & & & & & & $\ddot{x}$ & & & & \\
\hline Unique & & & & $\mathbf{X}$ & $\mathbf{X}$ & $x$ & & & & \\
\hline Sphingomonas (68 \%) & $\mathbf{X}$ & & & & & & $\mathbf{X}$ & & & \\
\hline Arthrobacter (95\%) & & & $\mathbf{X}$ & & & & & & & $\mathbf{x}$ \\
\hline NS & & & & & & & & & & $\mathbf{X}$ \\
\hline NS & & & & & & & & $\mathbf{x}$ & & \\
\hline Sphingomonas (72 \%) & $\mathbf{x}$ & & & & & $\mathbf{x}$ & & & & \\
\hline
\end{tabular}




\begin{tabular}{|c|c|c|c|c|c|c|c|c|c|c|}
\hline \multicolumn{11}{|l|}{ PLFA } \\
\hline Viable biomass, cells/ml & $8.60 E+03$ & $0.00 \mathrm{E}+00$ & $9.27 E+02$ & $3.49 \mathrm{E}+03$ & $2.95 \mathrm{E}+03$ & $3.29 E+04$ & $1.11 \mathrm{E}+04$ & $1.19 \mathrm{E}+05$ & $9.11 \mathrm{E}+06$ & $3.96 \mathrm{E}+03$ \\
\hline picomoles prokaryote PLFA/ml & 0 & 0 & 0 & 0 & 0 & 1 & 1 & 6 & 444 & 0 \\
\hline picomoles eukaryote PLFA/ml & 0 & 0 & 0 & 0 & 0 & 0 & 0 & 0 & 11 & 0 \\
\hline $\begin{array}{l}\text { ratio prokaryote:eukaryote } \\
\text { Metabolic Status: (Ratio) }\end{array}$ & $\mathrm{NC}$ & NC & $\mathrm{Nc}$ & $\mathrm{NC}$ & NC & 9 & 17 & 98 & 39 & 7 \\
\hline group A (cy17:0/16:1w7c) & 0 & NC & NC & 0 & 0 & 0 & 0.00 & 0 & 0.09 & NC \\
\hline group B (cy19:0/18:1w7c) & $\underline{0}$ & $\underline{N C}$ & $\underline{N C}$ & $\underline{0}$ & $\underline{N C}$ & $\underline{0}$ & $\underline{0.40}$ & $\underline{0}$ & $\underline{0.00}$ & $\underline{N C}$ \\
\hline Total & 0 & 0 & 0 & 0 & 0 & 0 & 0.40 & 0 & 0.09 & 0 \\
\hline group A (16:1w7t/16:1w7c) & 0 & NC & NC & 0 & 0 & 0.00 & 0 & 0.02 & 0.06 & NC \\
\hline group B (18:1w7t/18:1w7c) & $\underline{0}$ & $\underline{N C}$ & $\underline{N C}$ & $\underline{0}$ & $\underline{N C}$ & $\underline{0.17}$ & $\underline{0}$ & $\underline{0.00}$ & $\underline{0.09}$ & $\underline{N C}$ \\
\hline Total & $\overline{0}$ & $\overline{0}$ & $\overline{0}$ & $\overline{0}$ & 0 & 0.17 & $\overline{0}$ & $\overline{0.02}$ & $\overline{0.14}$ & $\overline{0}$ \\
\hline \multicolumn{11}{|l|}{ Community Structure: ( $\%$ of Total PLFA) } \\
\hline Firmicutes (TerBrSats) & 0 & 0 & 0 & 0 & 0 & 0 & 0 & 1.49 & 6.25 & 0 \\
\hline Proteobacteria (Monos) & 82.3 & 0 & 100.0 & 60.6 & 38.8 & 41.9 & 64.5 & 67.0 & 68.6 & 21.5 \\
\hline Anaerobic metal reducers (BrMonos) & 0 & 0 & 0 & 0 & 0 & 0 & 0 & 0 & 0 & 0 \\
\hline Actinomycetes (MidBrSats) & 0 & 0 & 0 & 0 & 0 & 30.1 & 0 & 0.6 & 0.8 & 0 \\
\hline General (Nsats) & 17.7 & 0 & 0 & 39.4 & 61.2 & 18.3 & 29.8 & 29.9 & 21.9 & 66.2 \\
\hline Eukaryotes (polyenoics) & 0 & 0 & 0 & 0 & 0 & 9.8 & 5.7 & 1.0 & 2.5 & 12.4 \\
\hline
\end{tabular}


WSRC-STI-2006-00340

January 2, 2007

Page 31 of 42

Table 4. Sequence analysis results

\begin{tabular}{|c|c|c|c|c|c|}
\hline \multirow[b]{2}{*}{ Band } & \multicolumn{3}{|c|}{ Similarity } & \multirow[b]{2}{*}{ Acceptors } & \multirow[b]{2}{*}{ Habitat } \\
\hline & Similar genus & Index & Donors & & \\
\hline$A, C$ & Failed & & & & \\
\hline $\begin{array}{l}\mathrm{B} \\
\mathrm{I}\end{array}$ & Beijerinckia & $\begin{array}{l}0.935 \\
0.935\end{array}$ & & & \\
\hline C & Erythrobacter & 0.972 & organics & $\mathrm{O}_{2}$ & $\begin{array}{l}\text { Marine aerobic phototrophic bacteria that are not } \\
\text { capable of anaerobic photosynthe sis }\end{array}$ \\
\hline $\begin{array}{l}D \\
P\end{array}$ & Ralstonia & $\begin{array}{l}0.964 \\
0.791\end{array}$ & $\begin{array}{l}\text { Chlorinated phenols, } \\
\text { organics }\end{array}$ & $\mathrm{O}_{2}$ & Freshwater and marine habitats \\
\hline E & Pelistega & 0.828 & & & \\
\hline $\begin{array}{l}F \\
G \\
J\end{array}$ & Sphingomonas & $\begin{array}{l}0.680 \\
0.724 \\
0.680\end{array}$ & $\begin{array}{l}\text { many organics, } \\
\text { recalcitrant } \\
\text { compounds }\end{array}$ & $\mathrm{O}_{2}$ & freshwater \& soil aerobe \\
\hline $\mathrm{H}$ & Roseateles & 1.000 & Organic compounds & $\mathrm{O}_{2},\left(\mathrm{NO}_{3}^{-}\right)$ & $\begin{array}{l}\text { Aerobic phototrophic bacteria that can survive } \\
\text { varving concentrations of oxvaen }\end{array}$ \\
\hline K & Hydrogenophaga & 0.836 & $\mathrm{H}_{2}$, organics & $\mathrm{O}_{2}$ & soil \\
\hline L & Aquaspirillum & 0.949 & organics & $\mathrm{O}_{2}$ & freshwater, soil \\
\hline $\begin{array}{l}\mathrm{M} \\
\mathrm{N}\end{array}$ & Rhodoferax & $\begin{array}{l}0.893 \\
1.000\end{array}$ & Low [ Sulfer] & $\mathrm{CO}_{2}$ & Contaminated soils Phototrophic \\
\hline $\begin{array}{l}0 \\
\mathrm{R}\end{array}$ & Propionovibrio & $\begin{array}{l}0.812 \\
0.941\end{array}$ & $\begin{array}{l}\text { Ferment aromatic } \\
\text { hydrocarbons }\end{array}$ & & Wastewater, Anaerobic, \\
\hline Q & Unique? & & & & Closest Muricauda 0.527 \\
\hline $\mathrm{S}$ & Unique? & & & & Closest Muricauda 0.491 \\
\hline $\mathrm{T}$ & Uncultured bacterium & 0.894 & & & AY093473 \\
\hline U & Uncultured bacterium & 0.757 & & & AY093464 \\
\hline V & Acidobacterium & 0.693 & & & \\
\hline W & Arthrobacter & 0.949 & wide range of.organics & $\mathrm{O}_{2}$ & a common soil organism,, canik nitrogen \\
\hline$x$ & Unique? & & & & Closest Lactobacillus 0.424 \\
\hline Y & Deinococcus & 0.873 & & & \\
\hline Z & Uncultured & 0.849 & & & AY510168 \\
\hline aa & Pseudomonas & 0.866 & small organics & $\mathrm{O}_{2},\left(\mathrm{NO}_{3}-\right)$ & soil, opportunist \\
\hline $\mathrm{bb}$ & Sulfuricurvum & 0.974 & $\begin{array}{l}\mathrm{S}=, \mathrm{S}^{0}, \mathrm{~S}_{2} \mathrm{O}_{3}=\mathrm{H}_{2} \\
\text { organo-sulfurs }\end{array}$ & $\begin{array}{l}\mathrm{NO}_{3}^{-} \text {, low } \\
\mathrm{O}_{2}\end{array}$ & $\begin{array}{l}\text { anaerobe to microaerophile capable of growing on } \\
\text { crude oil under anaerobic conditions. }\end{array}$ \\
\hline
\end{tabular}


WSRC-STI-2006-00340

Table 5. Transport test summary

\begin{tabular}{|c|c|c|c|}
\hline Monitoring & $\begin{array}{c}\text { Estimated } \\
\text { dispersivity } \\
\text { Well }\end{array}$ & $\begin{array}{c}\text { Estimated } \\
\text { TCFE retardation } \\
\text { factor, } \mathbf{L}\end{array}$ & $\begin{array}{c}\text { Estimated } \\
\text { TCFM } \\
\text { retardation } \\
\text { factor, } \mathbf{R}\end{array}$ \\
\hline 20 CL & 2.0 & 1.1 & 1.9 \\
\hline 43B & 0.7 & 2.5 & 5.1 \\
\hline 44A & 0.5 & 2.1 & 3.0 \\
\hline
\end{tabular}

Table 6. Estimated in situ reductive dechlorination rates for TCFE

\begin{tabular}{|c|c|}
\hline $\begin{array}{c}\text { Monitoring } \\
\text { Well }\end{array}$ & $\begin{array}{c}\text { Rate } \\
\text { (1/day) }\end{array}$ \\
\hline $3 \mathrm{D}$ & 0.001 \\
\hline $18 \mathrm{D}$ & $<0.0005$ \\
\hline $41 \mathrm{~A}$ & 0.002 \\
\hline $41 \mathrm{~B}$ & 0.001 \\
\hline $22 \mathrm{CL}$ & 0.004 \\
\hline $48 \mathrm{~A}$ & 0.002 \\
\hline $48 \mathrm{~B}$ & $<0.0005$ \\
\hline $42 \mathrm{~A}$ & $<0.0005$ \\
\hline $42 \mathrm{~B}$ & $<0.0005$ \\
\hline $44 \mathrm{~B}$ & $<0.0005$ \\
\hline
\end{tabular}


WSRC-STI-2006-00340

January 2, 2007

Page 33 of 42

Table 7. Model predictions and uncertainty analysis results

\begin{tabular}{|c|c|c|c|}
\hline \multirow{2}{*}{ Year } & \multirow{2}{*}{$\begin{array}{c}\text { Best Estimate of Source } \\
\text { Concentration }(\mu \mathrm{g} / \mathrm{L})\end{array}$} & Best Estimate & $95 \%$ UCL \\
\cline { 3 - 4 } & 1143 & 3.2 & 210 \\
\hline 1999 & 628 & 3.8 & 37 \\
\hline 2010 & 277 & 1.7 & 11 \\
\hline 2025 & 69 & 0.4 & 2.4 \\
\hline 2050 & & & \\
\hline
\end{tabular}



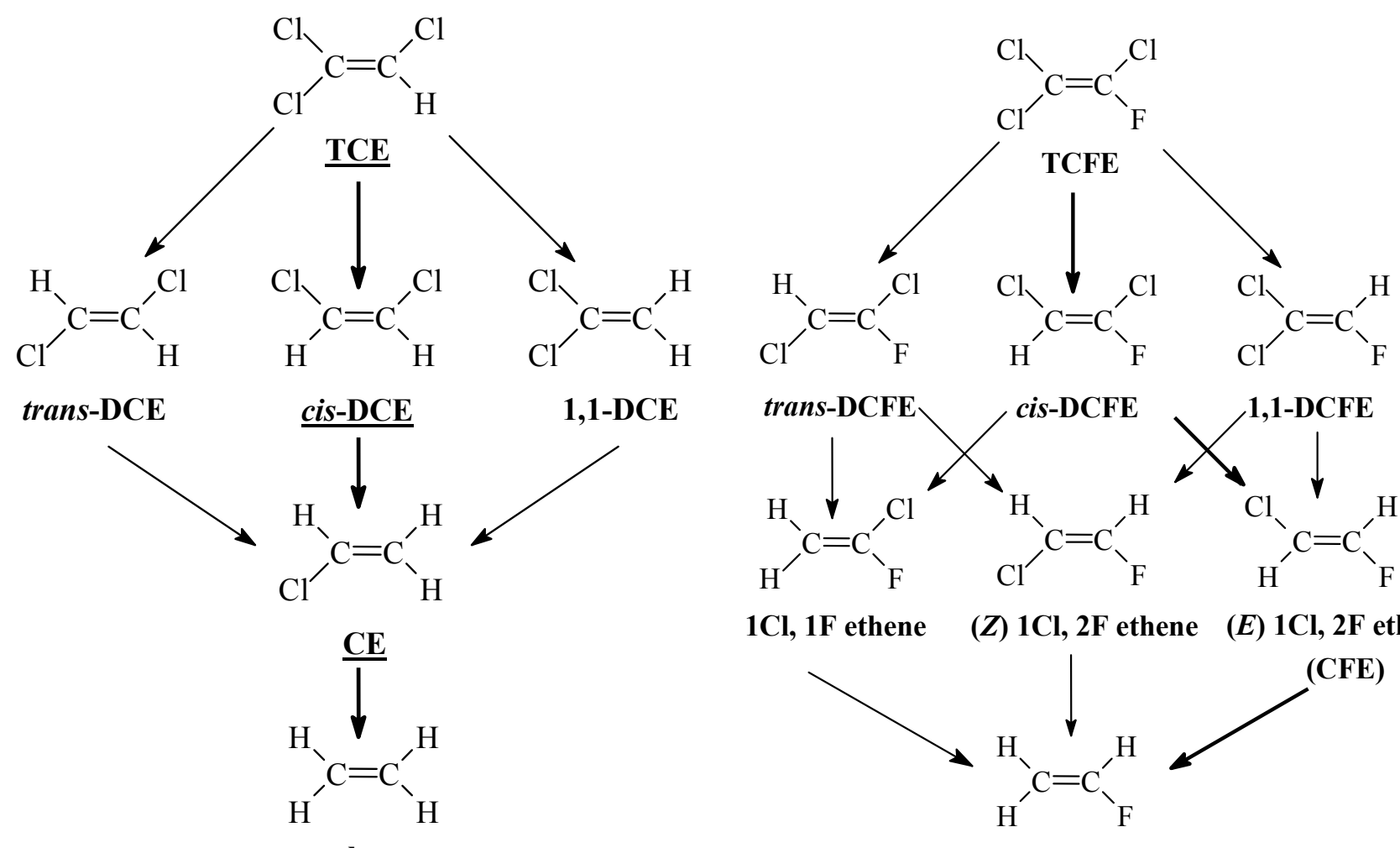

1Cl, $1 \mathrm{~F}$ ethene

(Z) 1Cl, 2F ethene

(E) $1 \mathrm{Cl}, 2 \mathrm{~F}$ ethene

ethene

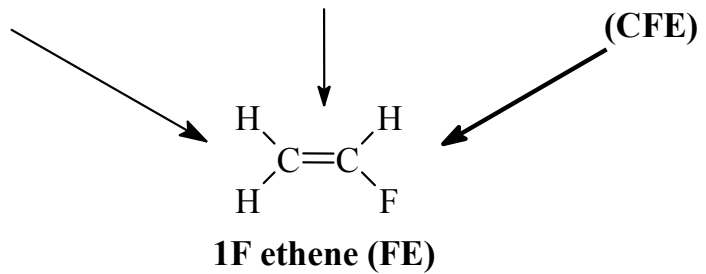

Figure 1: Reductive dechlorination pathways for TCE and TCFE showing transformation products that may be detected in field push-pull tests. Underlined compounds are the most commonly observed TCE transformation products.

Heavy arrows show major transformation pathways observed in laboratory and field studies. 
<smiles>ClC(Cl)(Cl)Cl</smiles>

Tetrachloromethane<smiles>C[Te]C(Cl)Cl</smiles>

Trichloromethane<smiles>CC(Cl)CCl</smiles>

Dichloromethane<smiles>CCl</smiles>

Chloromethane<smiles>FC(Cl)(Cl)Cl</smiles>

Trichlorofluoroemethane<smiles>[3H][3H]</smiles><smiles>FC(Cl)Cl</smiles>

Dichlorofluoromethane<smiles>CCC(F)Cl</smiles>

Chlorofluoromethane<smiles>CCCC</smiles>

Fluoromethane

Figure 2: Reductive dechlorination pathways for tetrachloromethane and TCFM showing transformation products that may be detected in field push-pull tests. 


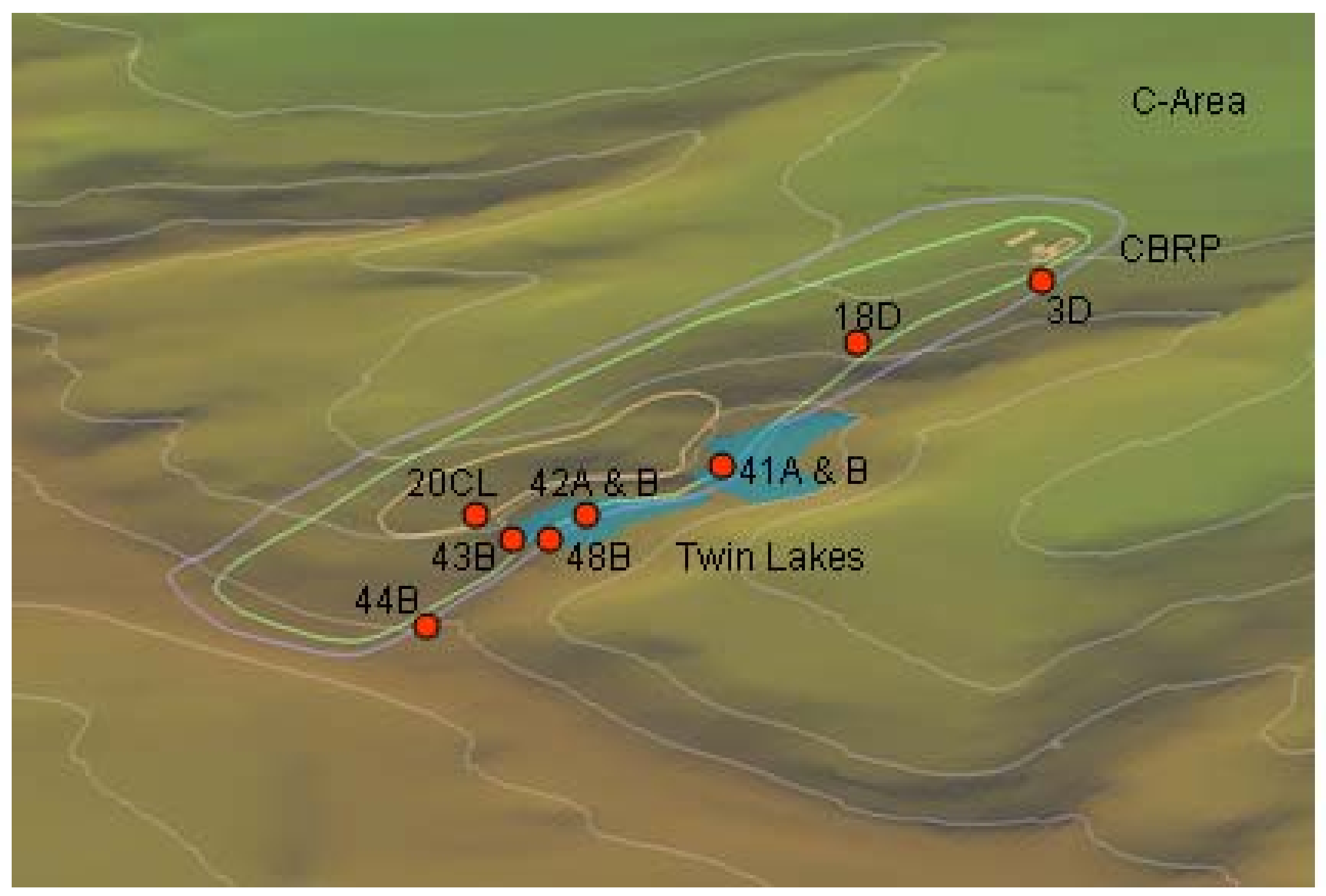

Figure 3: Location of test wells near CBRP. 


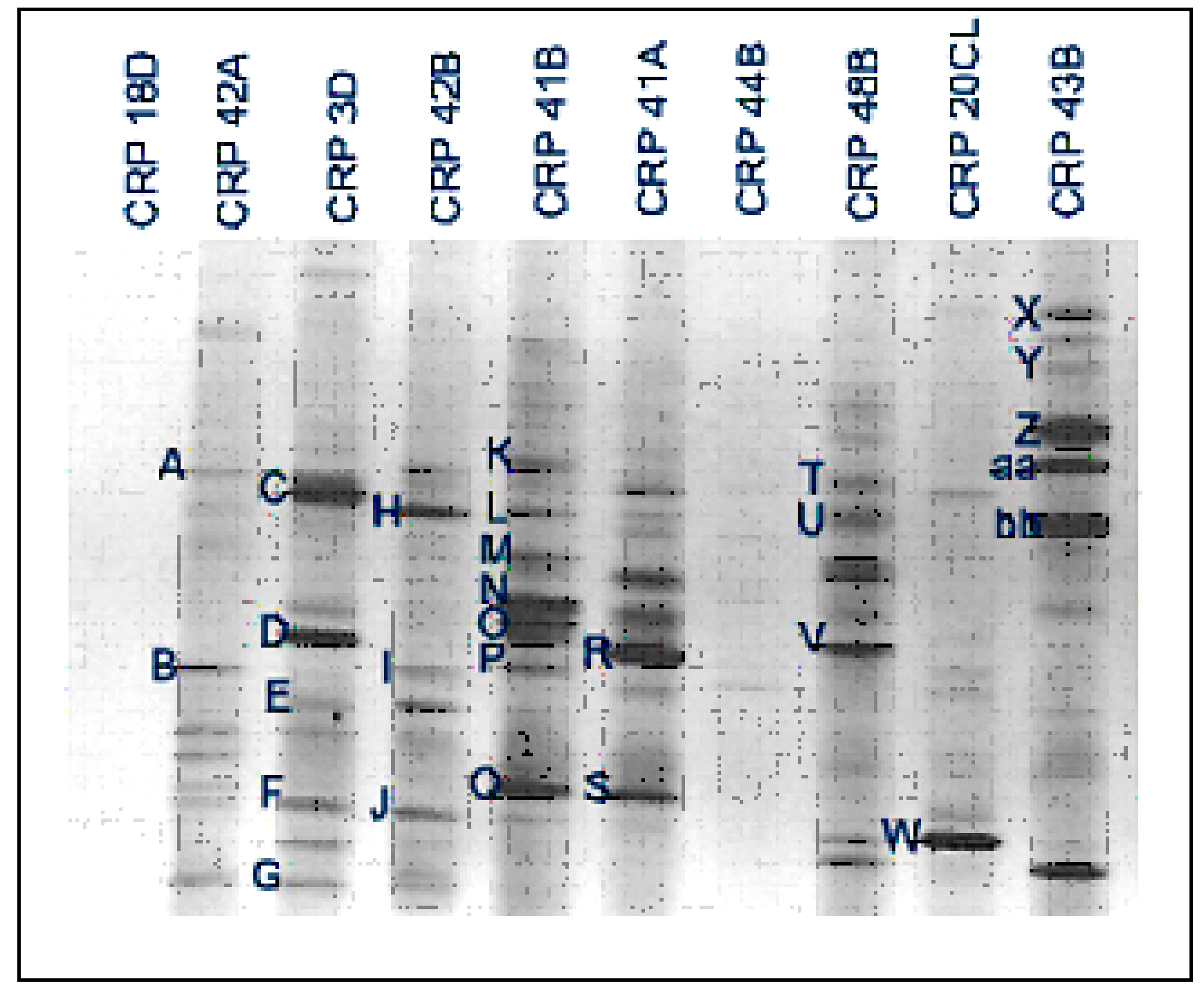

Figure 4. DGGE profiles of 16S rRNA genes amplified from DNA extracted from ground water samples 


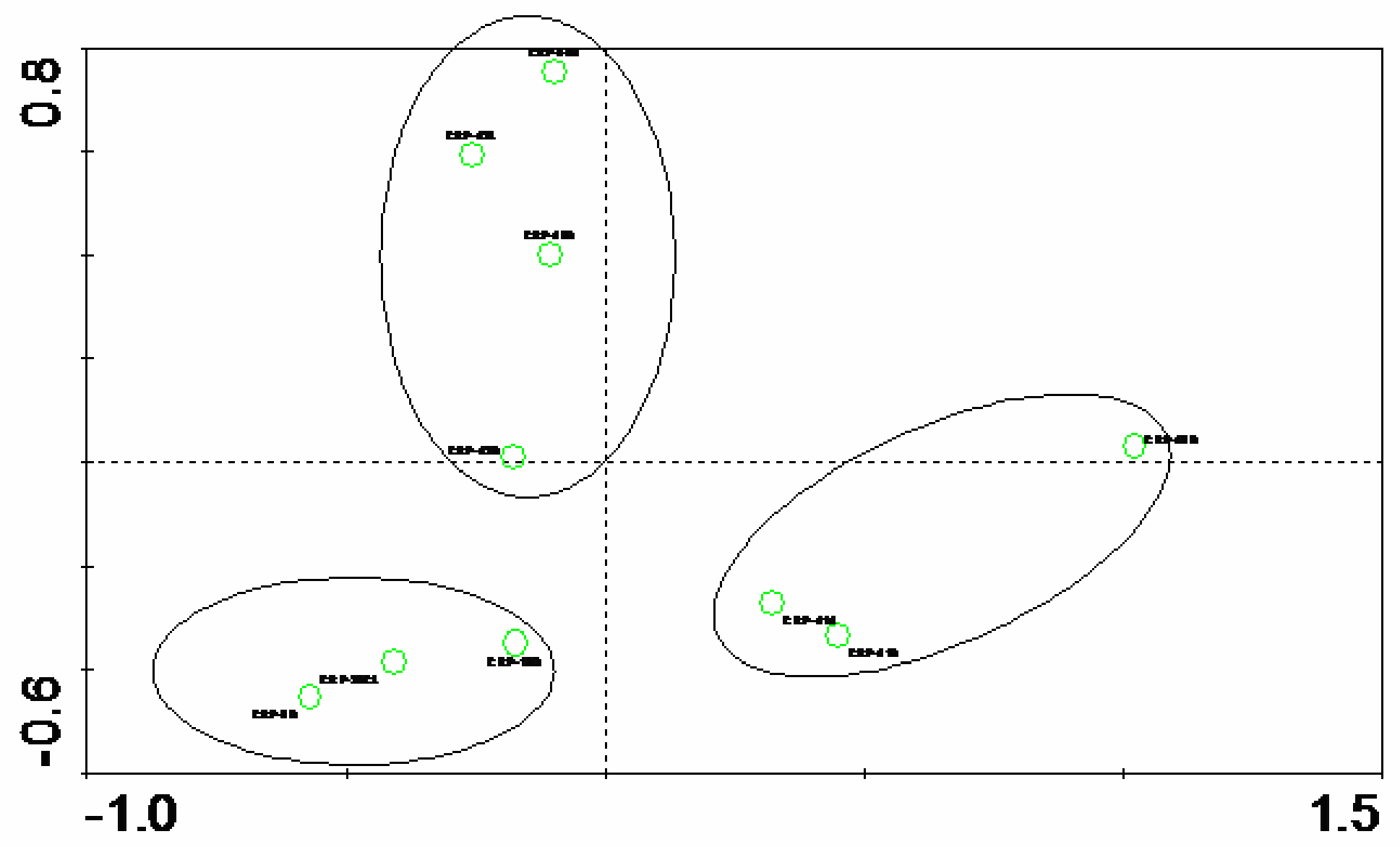

Figure 5. Principal component analysis (PCA) group separations. 


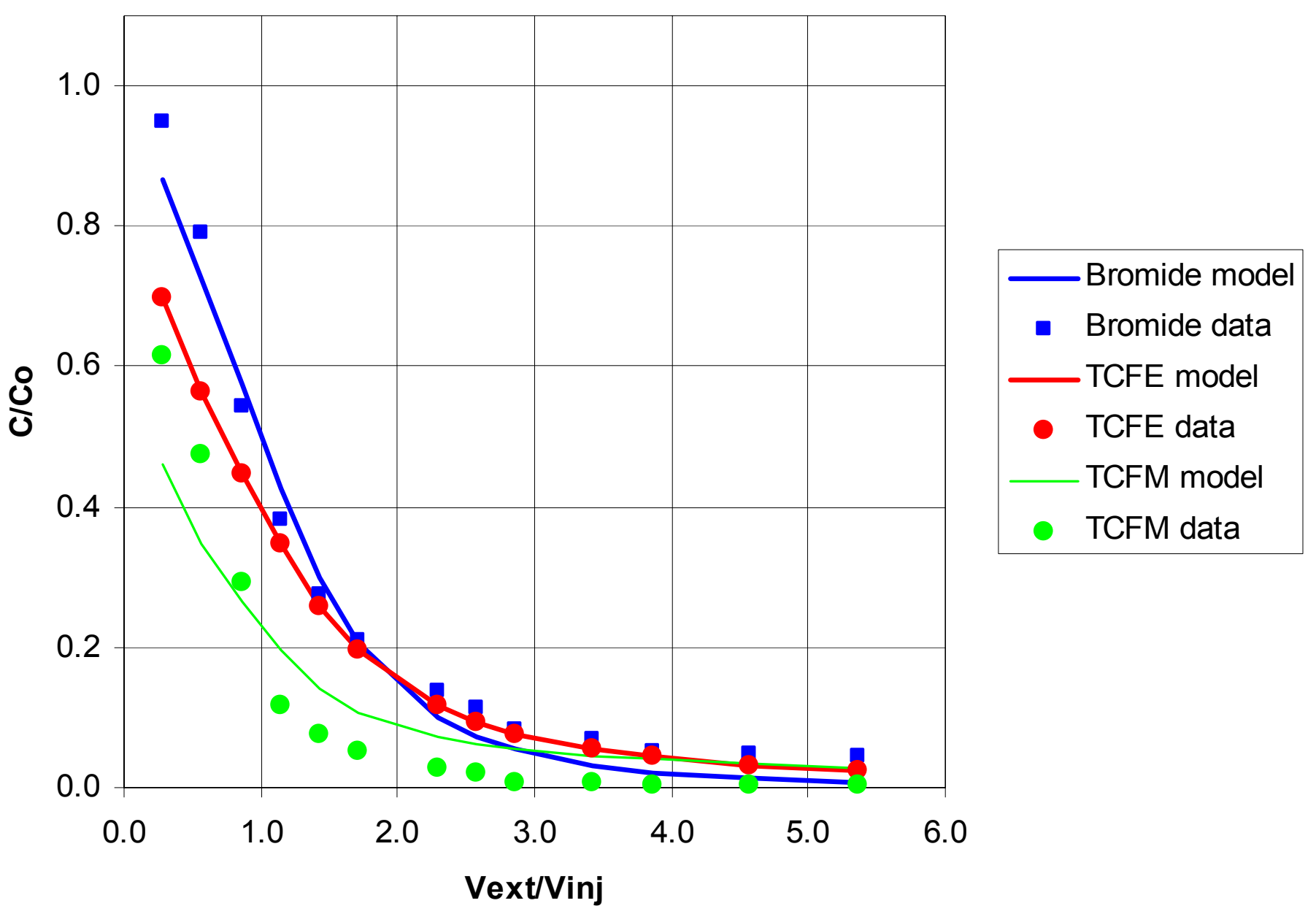

Figure 6. Transport test results for Test 10 (CRP-43B) showing increased dispersion for TCFE and TCFM compared to co-injected Br- For TCFE, fitted $R=2.5$; for TCFM, fitted $R=5.1$. 

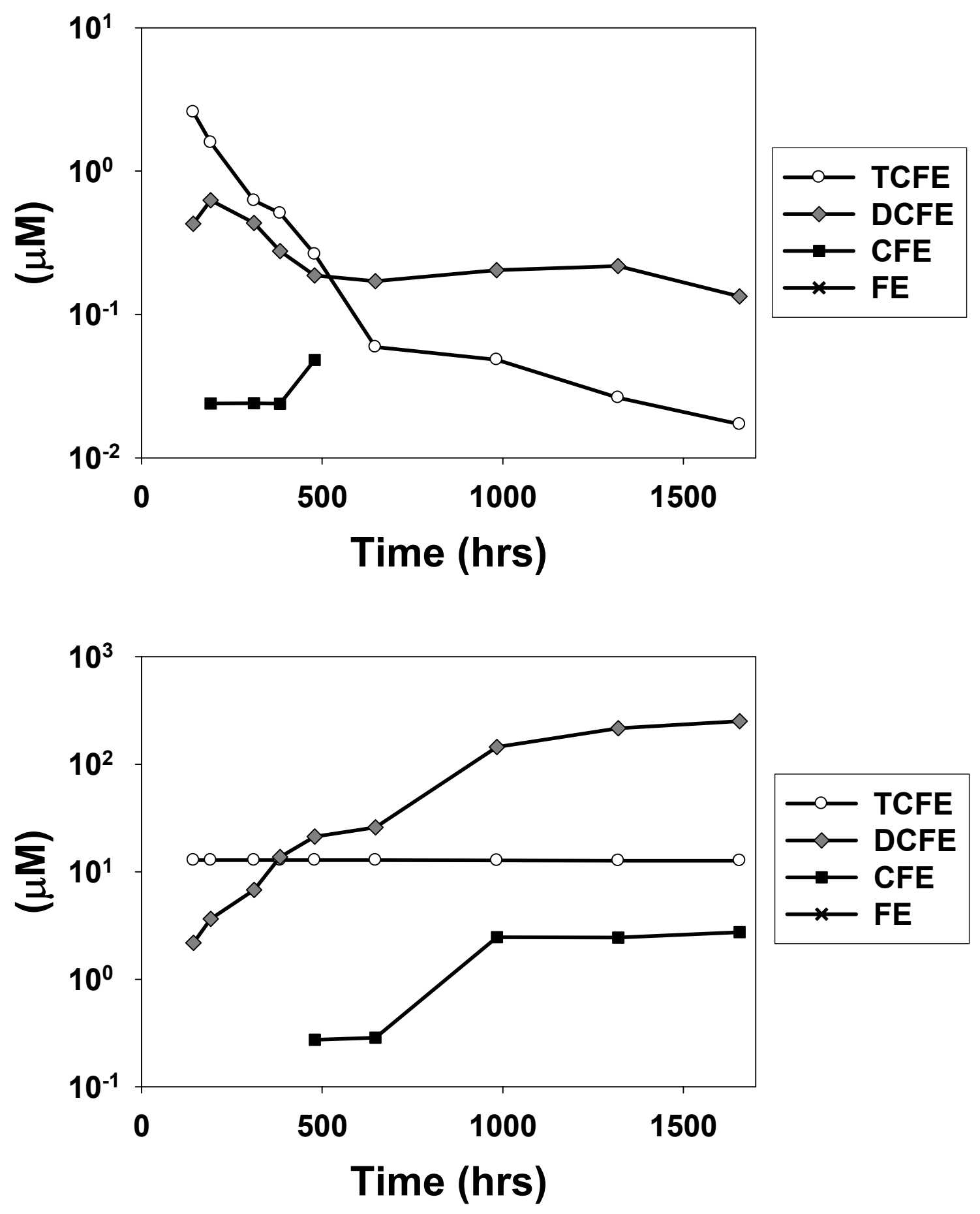

Figure 7. TCFE transformation test results for test 5, well 41B. Raw data (upper) and dilution adjusted data (lower). 

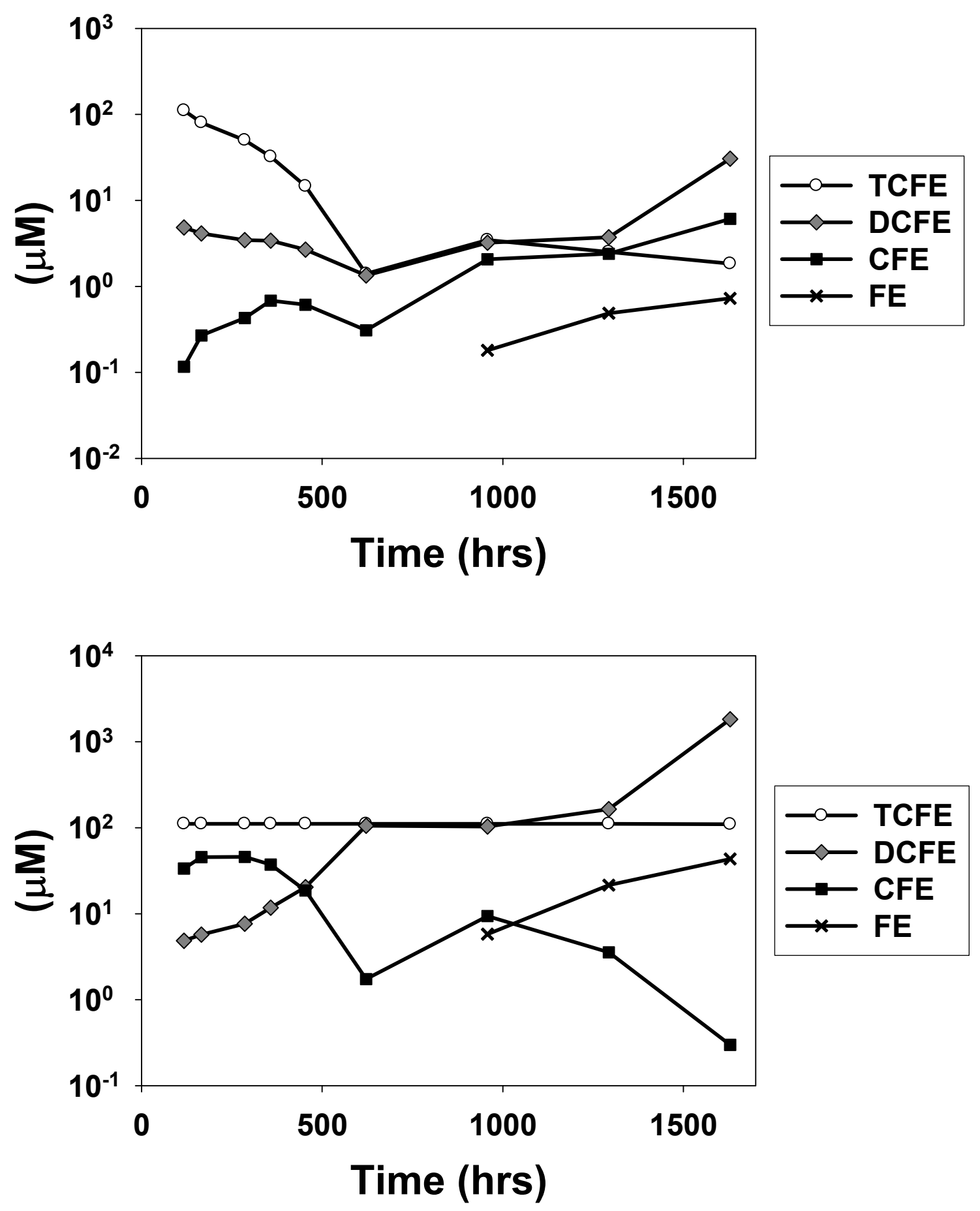

Figure 8. TCFE transformation test results for test 12, well 48A. Raw data (upper) and dilution adjusted data (lower). 

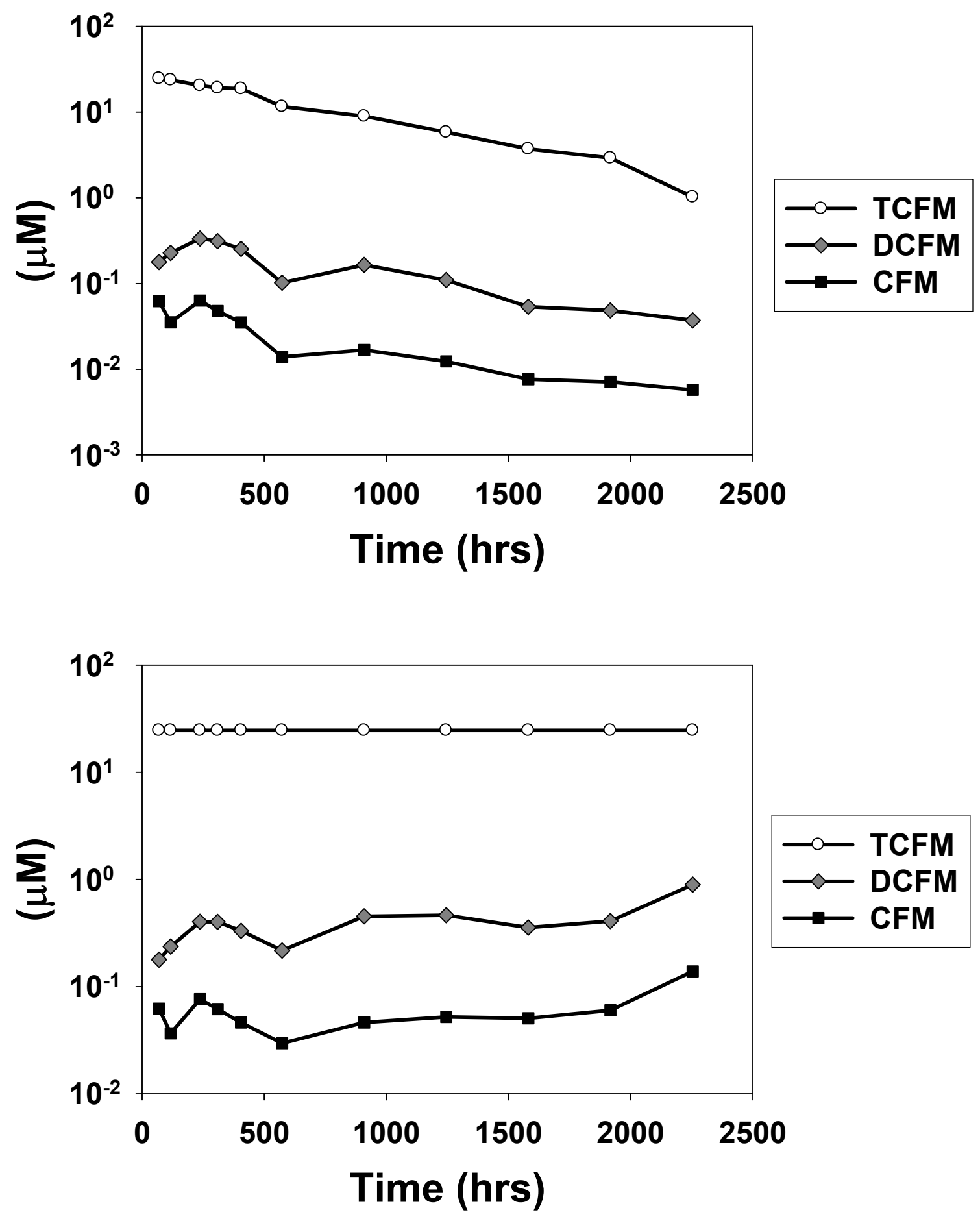

Figure 9. TCFM transformation test results for test 1, well 3D. Raw data (upper) and dilution adjusted data (lower). 